\title{
A Salgótarjáni és Ózdi paleogén részmedence térképezése szeizmikus és gravitációs mérési adatok alapján, és az eredmények szénhidrogén-földtani vonatkozásai
}

\author{
KovÁCs Zsolt, CSERKÉSZ-NAGY Ágnes, GuLYÁs Ágnes, Gúthy Tibor, KIsS János, \\ PÜSPÖKI Zoltán, SZENTPÉTERY Ildikó, SZALAY István \\ Magyar Bányászati és Földtani Szolgálat, H-1145 Budapest, Columbus utca 17-23. \\ kovacs.zsolt@mbfsz.gov.hu, cserkesz-nagy.agnes@mbfsz.gov.hu,gulyas.agnes@mbfsz.gov.hu,guthy.tibor@mbfsz.gov.hu, \\ kiss.janos@mbfsz.gov.hu,puspoki.zoltan@mbfsz.gov.hu, ildikoszentpetery@gmail.com
}

\section{Mapping of the Salgótarján and Ózd Palaeogene subbasins based on seismic and gravity measurement data, and its hydrocarbon geological aspects}

Abstract

Experts of the Hungarian Mining and Geological Survey prepared a detailed pre-Cenozoic basement map of the Salgótarján and Ózd Palaeogene subbasins (North Hungarian Palaeogene Basin, north-eastern Hungary), that area is still promising for both conventional and unconventional hydrocarbon exploration. During the preparation of hydrocarbon concession sensitivity-vulnerability studies in the area, came to light that the pre-Cenozoic basement maps made on the basis of data from wells drilled in the uplifted edges of the basin, depicted the depth of the basement morphology differently than had been expected on the interpretation of seismic depth sections. By that reason the estimation of hydrocarbon potential of the basin fill sediments was negatively affected. Therefore, the correct representation of the geometry of the basement and the marker horizons of basin fill with a more detailed resolution than is provided by the previous national scale maps are essential for judging better the hydrocarbon potential of the area.

The base of the work was the reinterpretation of partly reprocessed gravity and seismic data, archive subbasin depth maps and exploration drilling data of the Hungarian Geological, Mining and Geophysical Database. The 100-metre contour map shows the relief of the pre-Cenozoic basement from the basin surface outcrops to the deepest parts of $3400 \mathrm{~m}$ below sea level. Five marker horizons of the basin filling sediments were also interpreted.

According to the integrated seismic and gravity data interpretation along vertical cross-sections, significant difference can be detected between the north-eastern (Ózd subbasin) and western (Salgótarján subbasin) part of the studied area. The gravity basin model can be approached with two density models, including a transition zone between them. On the basis of the seismic interpretation, five main horizons can be observed in the Palaeogene - Lower Miocene sediments of the basin. Depth and thickness maps of potential source rocks were also prepared. According to the interpretation and mapping the Salgótarján subbasin is more extended and deeper than those of the previous overview maps. That affects positively the hydrocarbon potential in terms of quantity and maturity and the exploring of further occurrences.

Oil and natural gas occurrences and indications are well known in the area, indicating that in the southern part of the Ózd subbasin, towards the Salgótarján subbasin, source rocks of hydrocarbons are matured, the HC accumulations situated in or near the source rocks, and the migration is limited. According to the vitrinite reflectance data from wells deepened at the edge of the basin, the mapped near surface rocks had reached near the initial phase of the oil generation, so the studied basin area was buried deeper than at present. Based on depth maps and hydrocarbon geological data, we have estimated the amount of hydrocarbon generated by the Tard Clay, which can be exceeded 100 million cubic metres.

Keywords: seismic depth map, gravity depth map, pre-Cenozoic basement map, source rock maturity, hydrocarbon potential, vitrinite reflectance values, Rock-eval measurement data

Összefoglalás

Az Észak-magyarországi Paleogén-medence perspektivikus a szénhidrogének kutatása szempontjából. A kutatási lehetőségek megítéléséhez azonban elengedhetetlen a medencealjzat domborzatának, ill. az üledékkitöltés szintjeinek helyes ábrázolása. A Salgótarjáni- és Ózdi-részmedence területén a medenceperemi kutatófúrások alapján készült, országos léptékú prekainozoos medencealjzat-térképek a szeizmikus mélységszelvények alapján pontosíthatók. A Magyar Bányászati és Földtani Szolgálat (MBFSZ) szakemberei szeizmikus, gravitációs és mélyfúrási adatok újrafeldolgozása, újraértelmezése alapján elkészítették a terület részletes, nagyobb felbontású prekainozoos medencealjzat- 
térképét és az üledékkitöltés vezérszintjeinek térképeit. Az itt bemutatott eredmények alapján a paleogén medence aljzata a medenceperemektől Bárna település alatt (Salgótarjántól 10 km-re K felé) 3400 méter tengerszint alatti mélységig süllyed.

A geofizikai adatok együttes értelmezése szerint a Salgótarjáni- és az Ózdi-részmedence között jelentős eltérés van mind az aljzat mélysége, mind a medencét kitöltő üledékrétegsor tekintetében. A gravitációs medencemodell két sűrúségmodellel közelíthető, amelyek között egy átmeneti zóna is van. A szeizmikus értelmezés alapján a részmedencék paleogén-alsó-miocén üledékkitöltésében öt vezérszint követhetô, a nyugati részen (Salgótarjáni-részmedence) nagy vastagságban találhatók idősebb oligocén üledékek, míg az északkeleti területen (Ózdi-részmedence) a fiatalabb oligocén és miocén képződmények dominálnak. A potenciálisan anyakőzetként számon tartott összletekről mélység- és vastagságtérképek készültek. Ezek szerint a medence nyugati részének mélyzónája kiterjedtebb, mint azt a korábbi áttekintő térképek ábrázolják. A terület kőolaj- és földgáz-előfordulásai és -indikációi azt jelzik, hogy a Salgótarjánirészmedencében a szénhidrogének anyakőzetei érettek, a felhalmozódások pedig az anyakőzetekben vagy azok szúk környezetében lehetnek, mert a szénhidrogén migráció korlátozott. A vitrinit reflexió adatok szerint a medenceperemeken a jelenleg felszínközelben lévő megmintázott kőzetrészek szerves anyaga korábban a jelenleginél mélyebben volt eltemetve, és a kőolajképződés kezdeti fázisának közelébe jutott.

A Salgótarjáni-részmedencének a korábban vártnál nagyobb kiterjedése és mélysége, a várható szénhidrogén anyakőzetek mennyisége és érettsége alapján a terület $\mathrm{CH}$-potenciálja jelentősebb lehet a korábbi megítélésnél. A térképek és a szakirodalomból ismert szénhidrogén-földtani adatok alapján becslés történt az anyakőzet összlet által generált szénhidrogén mennyiségre, amely az értékelés szerint a 100 millió $\mathrm{m}^{3}$-t is meghaladhatja.

Tárgyszavak: szeizmikus mélységtérkép, gravitációs mélységtérkép, prekainozoos aljzatmélység, anyakózet érettség, szénhidrogén potenciál, vitrinitreflexió-értékek, Rock-eval mérési adatok

\section{Bevezetés}

A Salgótarjáni- és az Ózdi-részmedence területére esô szénhidrogén koncessziós érzékenység-terhelhetốségi tanulmányok készítésekor - melyet a Magyar Bányászati és Földtani Szolgálat (MBFSZ) állami feladatként lát el nyilvánvalóvá vált, hogy a rendelkezésre álló, fóként mélyfúrási adatokon alapuló, országos léptékú prekainozoos medencealjzat-térképek az aljzat mélységviszonyait a munkánk során készültt mélységbe konvertált 2D szeizmikus szelvények alapján értelmezettől eltérően ábrázolják, ami a medencekitöltố üledékek szénhidrogén-generáló potenciáljának megítélését is negatívan befolyásolja. Célunk az volt, hogy a rendelkezésre álló adatok felhasználásával tisztázzuk a vizsgált medencerészek mélységviszonyait, és adjunk egy nagyvonalú prognosztikus becslést arra, hogy ez hogyan befolyásolja a terület szénhidrogén potenciálját, várhatóan felfedezhető vagyonát.

A vizsgált terület (1. ábra) Magyarország északkeleti részén, az Észak-magyarországi paleogén-alsó-miocén Paleogén-medence részterületén helyezkedik el (1. ábra a, 2. ábra), a paleo-mezozoos kőzetekből álló Bükk hegység felszíni kibúvásától nyugatra, a miocén vulkanitokból felépült Mátra hegység északi oldalán. A négyzettel határolt területen belül a részletesen vizsgált rész kiterjedése mintegy $1500 \mathrm{~km}^{2}$ (1. ábra d). Ennek ÉK-i, K-i medencéje a földtani szakirodalomban Ózd-Egercsehi-medence, Nyugat-Borsodi-medence, Rimava-Ózd-medence neveken ismert, Ny-i része a Nógrádi-medence Salgótarjáni-részmedencéjének (NAGYMAROSI 2012) keleti pereme. Ebben a munkában a területeket Ózdi-részmedence és Salgótarjánirészmedence néven említjük ( 1 . ábra $a$ ). A két medence elhatárolása hozzávetôlegesen az Ózdtól Fedémes felé húzódó aljzati gerinc mentén vonható meg.

A terület medencealjzatának domborzatáról két, országos léptékú, felbontásában és szintvonalainak rajzolatában is hasonló kivágat állt rendelkezésre (TANÁCS \& RÁLISCH 1990, KILÉNYI et al. 1991; 1. ábra a és b), illetve HAAs (2010) prekainozoos aljzattérképén is szerepelnek mélység szintvonalak (1. ábra c). Ezek elsősorban az aljzatot elért peremi helyzetú mélyfúrások adatait használták fel. A területről elérhető gravitációs és szeizmikus adatok azonban árnyalják a képet. Ez indokolta, hogy az MBFSZ szakemberei a rendelkezésre álló geofizikai, földtani és kőolajföldtani adatok alapján egy új, részletes és egységes szemléletú medencealjzat-térképet készítsenek (Kovács et al. 2015).

\section{Kutatástörténet}

A 18. században felfedezett Parád (BEAUdANT 1822, Tóth 1882) és Recsk (KITAIBEL 1829; MATYASOVSZKY 1885; PosEWITZ 1906; RozLOZSNYIK 1939, 1941) környéki szénhidrogén-indikációk kutatására az Eötvös Loránd Geofizikai Intézet (ELGI) 1933 és 1937 között végzett gravitációs méréseket, melyek szerkezeti boltozatokat mutattak ki. Bükkszéknél földtani térképezéssel kimutatott antiklinálisra (SCHRÉTER 1936, 1951; 3. ábra) fúrták a Bükkszék Bsz-1 fúrást, amelyből napi 2001 kőolajat termeltek. Ez volt a mai Magyarország elsô kôolajtermelô kútja, de gazdasági értéke meg sem közelítette a kissé később termelésbe állított Budafa-2-ét. A területen összesen 56 fúrást mélyítettek, és két telítetlen kőolajtelep vált ismertté az alsó-oligocén Kiscelli Agyag Formáció turbidites homokkő rétegeiben és vulkáni tufapadokban. 1940 májusáig összesen 10000 tonna kőolajat termeltek ki (TelEGdi Roth 1951). Az 1940-ben mélyült Nagybátony Nb-I fúrásban és környezetében a felszínen, valamint a környékbeli kôszénbányák táróiban is előfordulnak kőolaj-indikációk.

A terület legjelentősebb szerkezeti mélytörésének, a Darnó-vonalnak - mely egyben a szúkebb vizsgálati területünk (1. ábra d) keleti határát is adja - felismerése is a 

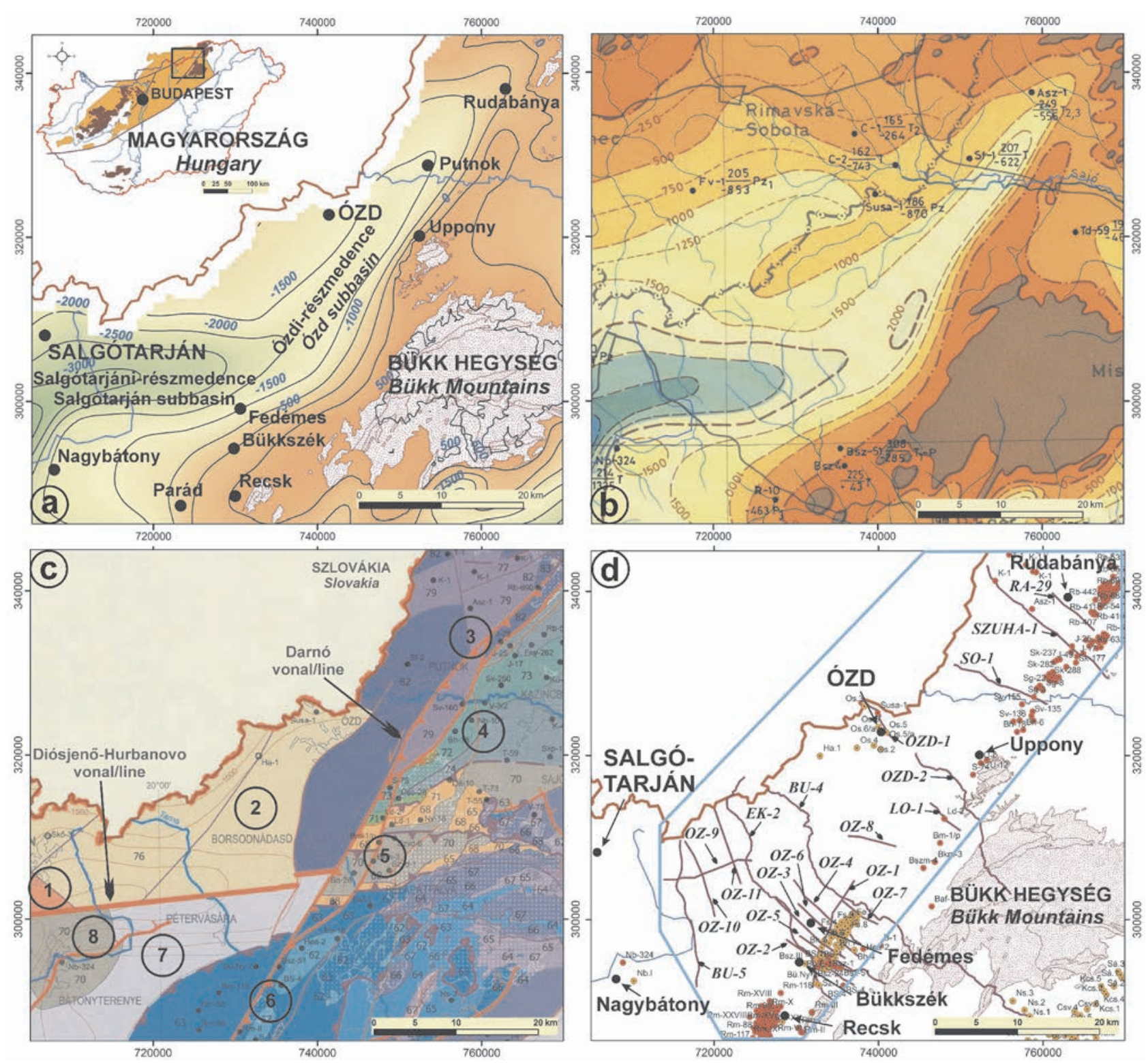

1. ábra. A terület prekainozoos medencealjzatának domborzata TANÁCS \& RÁLISCH (1990) (a) és KILÉNYI et al. (1991) szerint (b) - a narancssárga folt az (a) ábrarész Magyarország térképén a Paleogén-medence kiterjedését mutatja TARI et al. 1993 alapján. A vizsgált részmedencék aljzatának földtani felépitése Magyarország prekainozoos földtani térképén HAAS et al. (2010) alapján (c). A prekainozoos aljzatot elért kutatófúrások (piros kör) és a szénhidrogén-kutató fúrások (sárga kör) helye, az értékelésbe bevont 2D szeizmikus reflexiós szelvények nyomvonala - a kék vonallal határolt magyarországi területrészt vizsgáltuk részletesen (d). Koordinátarendszer: HD-1972, EOV

Jelmagyarázat a (c) ábrához: 1. Vepori-egység, közepes fokú polimetamorf komplexum; 2. Gömöri-egység, paleo-mezozoos kőzetek; 3. Aggtelek-Rudabányai-egység, triász karbonátos kőzetek, homokkövek; 4. Szendő-Upponyi-egység, kis fokú metamorf devon-karbon karbonátos kőzetek, karbon törmelékes kőzetek, senon konglomerátum; 5. Bükki-egység, nagyon kis fokú metamorf felső-paleozoos tengeri üledékek, felső-perm-alsó-triász sekélytengeri mészkő, homokkő, márga; 6. Bükki-egység, triász-jura karbonátos kőzetek, agyagpala, vulkanitok; 7. Bükki-egység, nagyon kisfokú metamorf felsö-paleozoos és mezozoos kőzetek; 8. Bükki-egység, nagyon kis fokú metamorf felsö-paleozoos tengeri üledékek

Figure 1. Pre-Cenozoic basement depth map according to TANÁCS \& RÁLISCH (1990) (a) and KILÉNYI et al. (1991) - the orange patch on the map of Hungary on Figure (a) represents the extent of the Palaeogene Basin (b); Geological map of the pre-Cenozoic basement based on HAAS et al. (2010) (c); Wells reached the basement (red circles), hydrocarbon exploration wells (orange circles), and the lines of 2D seismic sections interpreted in this work (with Palaeo-Mesozoic basement outcrops in the background) - the Hungarian part of the area bordered by blue line was studied in detail (d). Coordinate system: HD-1972, EOV Hungarian Natonal Grid

Legend for the figure (c): 1. Vepor Unit, medium-grade polimetamorphyc complex; 2. Gemer Unit, Paleo- and Mesozoic rocks; 3. Aggtelek-Rudabánya Unit, Triassic carbonates, sandstones; 4. Szendö-Uppony Unit, low-grade metamorphyc Devonian-Carboniferous carbonates, Carboniferous siliciclastic rock, Senonian conglomerate; 5. Bükk Unit, Very low-grade metamorphyc Upper Palaeozoic marine sediments, Upper Permian - Lower Triassic shallow marine limestone, sandstone, marl; 6. Bükk Unit, Triassic-Jurassic carbonates, shales, volcanites; 7. Bükk Unit, very low-grade metamorphyc Upper Palaeozoic and Mesozoic rocks; 8. Bükk Unit, very low-grade metamorphyc Upper Palaeozoic marine sediments

Recsk melletti Darnó-hegy-Bükkszék környezetében az 1930-as és 40-es években szénhidrogén-földtani céllal végzett kutatások eredménye (TELEGDI RoTH 1937). A korabeli megfigyeléseket (SCHRÉTER 1942, 1951; MAJZON 1940; JASKó 1946; SZENTES 1951a, b) az évtizedekkel késóbbi bükk- széki és fedémesi kutatási területeken végzett szeizmikus mérések (Szalay \& Zelenka 1979; Albu et al. 1985; Braun et al. 1989. Petrovics \& Szalay 1992, 1998) megerősítették.

A Bükkszék környezetében megismert feltolódást jelen- 


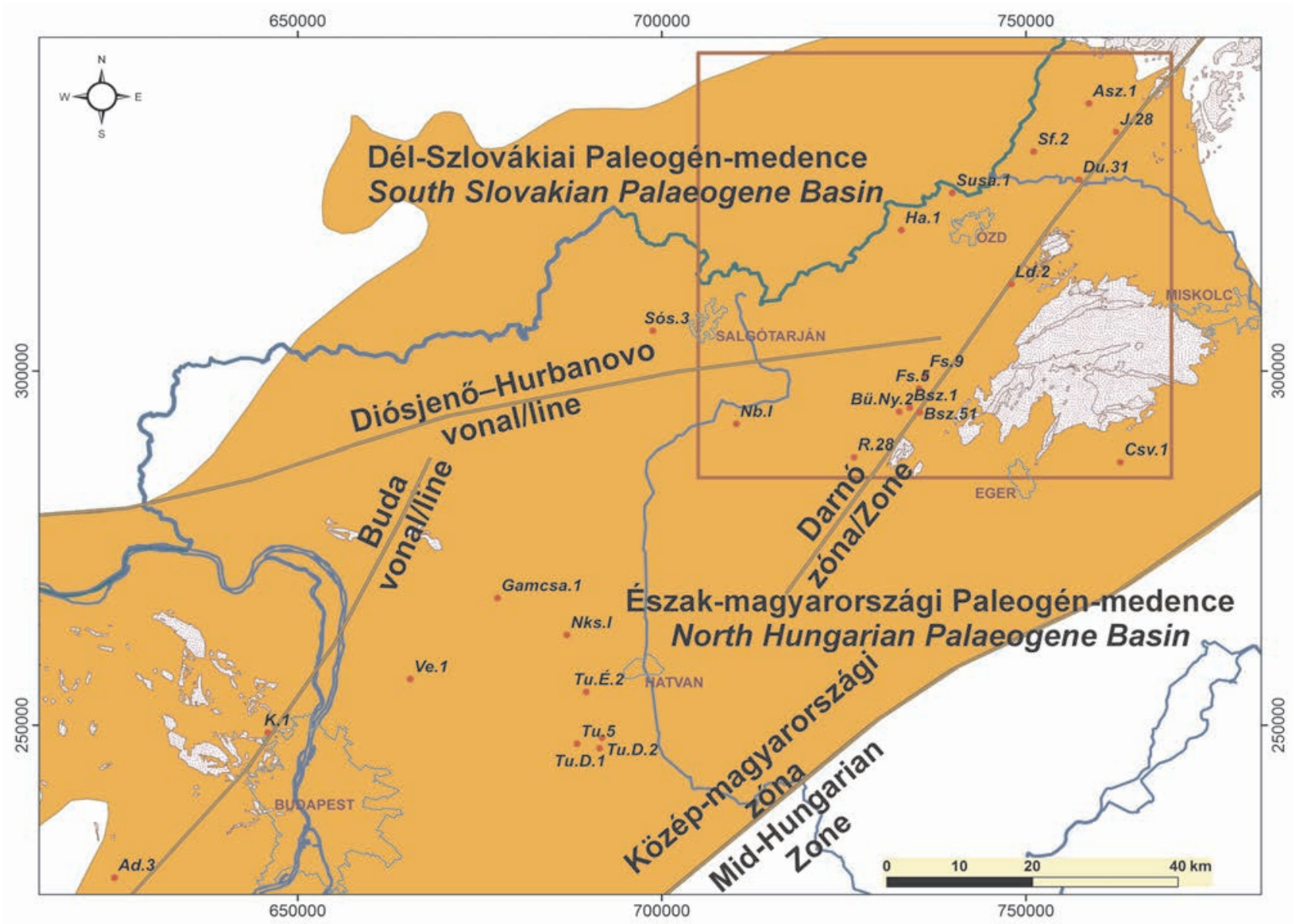

2. ábra. Az Észak-magyarországi és Dél-szlovákiai Paleogén-medence kiterjedése TARI et al. 1993 alapján a négyzet alakú vizsgált terület környezetében, a cikkben hívatkozott kutatófúrásokkal

Figure 2. Extent of the North Hungarian - South Slovakian Palaeogene Basin based on TARI et al. 1993in the surroundings of the square shaped studied area, with the referred exploration wells

leg Darnó-vetô néven említik (FodOR et al. 2005), a szerkezet ÉÉK-i irányban egészen a Rudabányai-hegységig folytatódik (PANTó 1956), ahol is a Rudabányai-hegység K-i, Ny-i esetleg mindkét peremén futva Dél-Szlovákiáig tart (HERNYÁK 1977, GriLL et al. 1984, RADÓCZ 1987a, Less et al. 1988, SZENTPÉTERY 1997, VASS 2002).

Ózd környékén az első graviméteres méréseket a Magyar Állami Eötvös Loránd Geofizikai Intézet (MÁELGI) végezte 1950-60 között, a járható utak mentén. Szabályos hálózatban végzett mérések csak 1992-93-ban készültek. Az első mágneses méréseket szintén a MÁELGI végezte az 1950-es években. Az 1950-es évek második felében mélyítették a terület északi részén a Hangony, $\mathrm{Ha}-1$, délen pedig a fedémesi fúrásokat. A fedémesi éghetőgáz-előfordulást a Fedémes, Fs-9 fúrással 1958-ban fedezték fel. Tárolókôzete alsó-oligocén kiscelli homokkő, agyagmárgás homokkő (Kiscelli Agyag Formáció) (VöLGYI et al. 1985). A Fedémes, Fs-5 fúrásban 1616 és 1830 m között a Tardi és Kiscelli Agyag kôolajnyomos volt (KóRössy 2004).

Az Eötvös Loránd Geofizikai Intézet (ELGI) 1986 és 1993 között geofizikai (geoelektromos, magnetotellurikus, szeizmikus refrakciós és reflexiós) méréseket végzett a Darnó-zóna környezetében, a Központi Földtani Hivatal által indított „A Bükk-hegység és elôterei komplex földtani előkutatási programja" keretében (SZALAY 1998).

A MOL Magyar Olaj- és Gázipari Rt. 1992-tốl kezdett kutatási tevékenységet az Ózdi-medence területén (HAJDÚ et al. 1997), melynek keretében gravitációs, mágneses, geoelektromos és szeizmikus reflexiós méréseket folytattak. Ebben az időszakban került sor az Oz-1-Oz-11 jelú szeizmikus reflexiós vonalak mérésére. Kutatófúrás mélyítéséről a magas geológiai kockázat miatt lemondtak. Az Ózdimedence Zagyva-árok felé való kapcsolódási területét is érintette a MOL 1999 és 2002 között Salgótarján, illetve 2004 és 2012 között a Bátonyterenye védnevú szénhidrogén kutatási területen végzett tevékenysége (KósA et al. 2003, BoncZ et al. 2012). Ezekben a kutatási periódusokban mérték be a Sal jelú szeizmikus reflexiós vonalakat.

\section{Földtani környezet}

A vizsgált területen (1. ábra) a Darnó szerkezeti vonal két oldalán a földtani ismeretesség nagyon különböző. A Ny-i oldalon, a mélyebb medencerészeken kevés fúrás van, a Darnó-zóna és a K-i oldal felszíni, fúrási, geofizikai ada- 


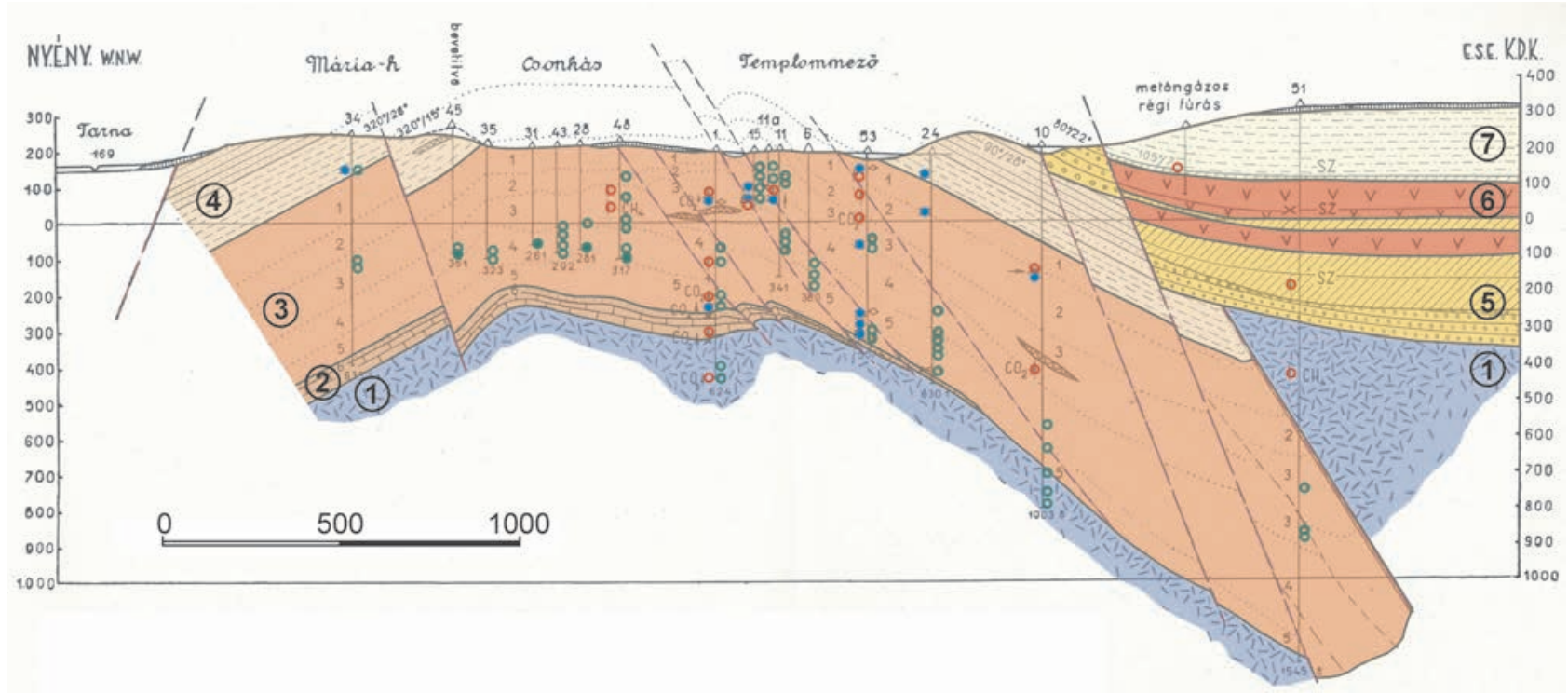

3. ábra. A bükkszéki boltozat földtani szelvénye kőolajkutató fúrások alapján (SCHRÉTER 1951)

Jelmagyarázat: 1. Prekainozoos aljzat, középső-felső-jura mélytengeri mészkő, palás aleurolit, agyagpala, radiolarit (Mónosbéli Formációcsoport); 2. Felső-eocén sekélytengeri lithothamniumos mészkő (Szőci Mészkő), felső-eocén-alsó-oligocén nyilt tengeri márga (Budai Márga) és alsó-oligocén agyagmárga (Tardi Agyag); 3. Alsó-oligocén nyílt tengeri agyag, agyagmárga, andezittufa betelepülésekkel (Kiscelli Agyag F.); 4. Felső-oligocén-alsó-miocén tengeri-sekélytengeri agyag, homokos agyag, homokkő (Szécsényi Slír, Pétervásárai Homokkő); 5. Alsó-miocén sekély tengeri, folyóvízi, mocsári kavics, homok, agyag, vörös agyag (Zagyvapálfalvai F.); 6. Alsó-miocén riolittufa (Gyulakeszi Riolittufa); 7. Alsó-miocén sekély tengeri chlamysos-corbulás homok, homokkő, agyag (Egyházasgergei F.); (részben GYALOG et al. 2013 alapján). Zöld pont: kőolajtermelés; zöld karika: kőolajnyom; piros karika: gázbeáramlás, nyom; kék pont: sós víz beáramlás

Figure 3. Geological section of the Bükkszék anticline based on oil exploration wells (SCHRÉTER 1951)

Legend: 1. Pre-Cenozoic basement, Middle-Upper Jurassic deep-marine limestone, foliated siltstone, shale, radiolarite (Mónosbél Group); 2. Upper Eocene shallow-marine lithothamnium limestone (Szöc Limestone), Upper Eocene - Lower Oligocene open-marine marl (Buda Marl) and Lower Oligocene clay marl (Tard Clay); 3. Lower Oligocene open-marine clay, clay marl, andesite tuff intercalations (Kiscell Clay); 4. Upper Oligocene - Lower Miocene marine-shallow-marine clay, sandy shale, sandstone (Szécsény Slirr, Pétervására Sandstone); 5. Lower Miocene shallow water, fluvial and paludal gravel, sand, clay, red clay (Zagyvapálfalva Fm); 6. Lower Micene rhyolite tuff(Gyulakeszi Fm); 7. Lower Miocene shallow-marine sand, sandstone, clay; (partly based on GYALOG et al 2013). Green point: crude oil production; green circle: oil show; red circle: gas inflow; blue circle: saltwater inflow

toknak és ismereteknek bővében van. Ezek alapján a terület prekainozoos aljzata (1. ábra c, HAAs et al. 2010) három fó részre különül. A Darnó-vonalig húzódó, közel Ny-K-i csapású Diósjenő-Hurbanovo (Ógyalla)-vonal É-i oldalán Nyról K felé haladva az Alcapa-fóegység Nyugat-kárpáti egységeihez tartozó Vepori (1), Gömöri (2) és Aggtelek-Rudabányai-egység (3) képződményei találhatók, a vonaltól D-re részben feltételesen, ill. részben bizonyosan a Bükki-egység $(6,7,8)$ különböző korú és kifejlődésú képződményei helyezkednek el (HAAs \& BUDAI szerk. 2014). A vizsgált terület Darnó-feltolódástól K-re eső részén az Aggtelek-Rudabányai- (3), a Szendrő-Upponyi- (4) és a Bükki-egység (5, 6) zömmel felszínen, valamint a medencealjzatban megjelenő képződményei találhatók.

A vizsgálati terület jelenlegi adottságait két eltérő medencefejlődési időszak, a paleogén-kora-miocén Paleogénmedence, és a késôi kora-miocéntôl alakuló Pannon-medence szerkezetfejlődési eseményei alakították. A medence szénhidrogénföldtani potenciálja a Paleogén-medence szénhidrogén rendszere elemeire vezethető vissza, a medenceszerkezetet azonban jelentősen felülbélyegezték a neogén szerkezeti eseményei (FoDOR et al. 2005, Szócs et al. 2015, PETRIK et al. 2016, BEKE et al. 2019).

A magyarországi Paleogén-medence észak-magyarországi része egy DNy-ÉK csapású övben helyezkedik el, a Közép-magyarországi szerkezeti zónától északra. Kialakulásának meghatározó, számos rétegtani adattal alátámasz- tott sajátossága a depocentrum időben elhúzódó, több szakaszban ÉK felé történő vándorlása. A vizsgált részterületen (1., 2. ábra) az üledékképződés feltehetően csak az eocén végén (priabonai NP19-20) indult meg, ugyanakkor a miocén eggenburgi emeletének végéig (NN3) folyamatos volt (BÁLDI 1980, 1983; TARI et al. 1993; 4. ábra).

A Paleogén-medence depocentrumának ÉK-re vándorlását, illetve a medence ősföldrajzi kapcsolatait több fejlődéstörténeti modell is magyarázza (KÁzMÉr 1984, BÁLDI \& BÁLdiné 1985, RoYdEn \& BÁldi 1988, FodOR \& KÁZMÉR 1989, Fodor et al. 1992, KÁZMÉr et al. 2003), melyek szerint a medence fejlődését annak D-i peremén jelentkező, a középső-eocéntől a késő-oligocénig tartó közel folyamatos jobbos eltolódás határozta meg, és a térrövidüléssel jellemezhető Külsô-Kárpátok és az ugyancsak térrövidülést mutató Dinaridák közötti átmeneti helyzetû transztenziós szerkezettel értelmezhetô. A medence dél felé vetővel csonkolt, másik része Szlovéniában van (BÁLDI 1983, NAGYMAROSY 1990, FODOR et al. 1999). TARI et al. (1993), SZTANÓ \& TARI (1993) szerint a Paleogén-medence fejlődése egy a Nyugati-Kárpátok hátterében az Európai-tábla D-i irányú szubdukciójával egy időben kialakuló visszatorlódásosrövidüléses medence (retroarc flexural basin) modelljével magyarázható. A jelenlegi megítélés szerint az Északmagyarországi Paleogén-medence szerkezete dominánsan rövidüléses mozgások következtében alakult ki (FoDOR et al. 2005; FodOr 2010; PETRIK et al. 2014, 2016). 


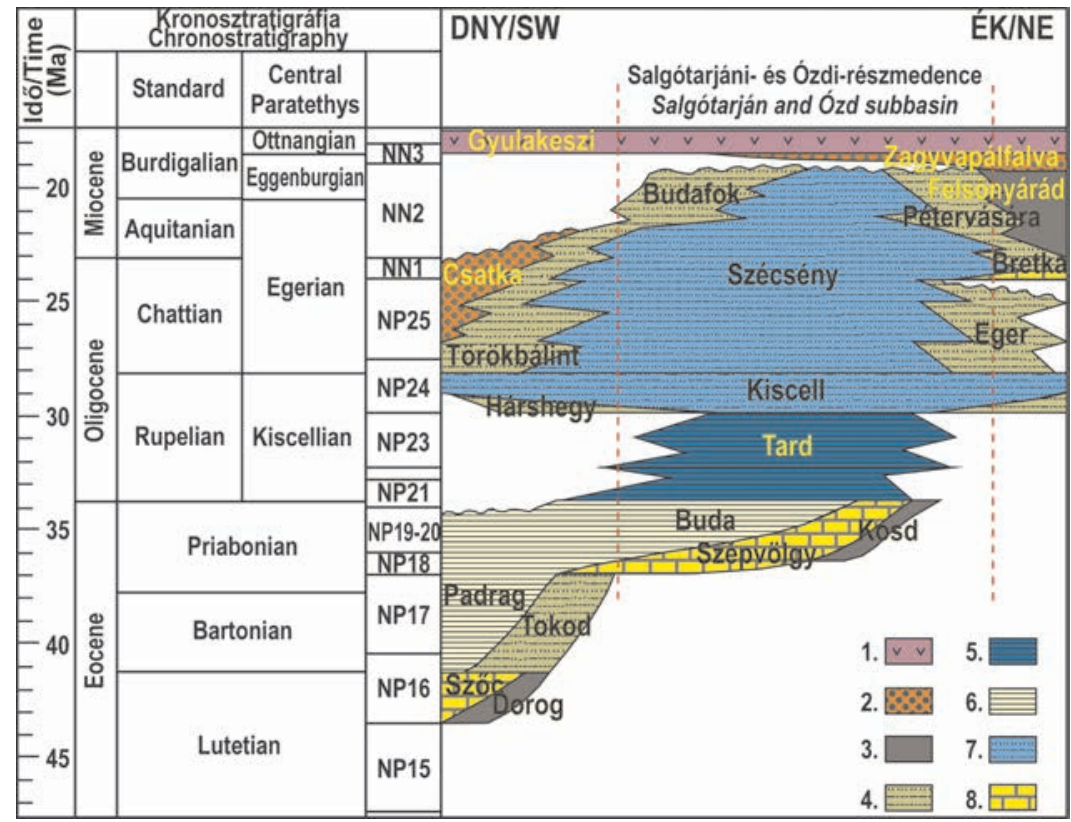

4. ábra. A paleogén üledékciklus litosztratigráfiai összefüggései az Észak-magyarországi Paleogénmedencében TARI et al. (1993) alapján

Jelmagyarázat: 1. savanyú piroklasztikumok; 2. szárazföldi törmelékek, alluviális homokos és kavicsos üledékek; 3. part menti, paralikus, mocsári üledékek; 4. sekély tengeri, partközeli sziliciklasztos üledékek; 5. nyílt tengeri, batiális, euxin mélymedence agyagos képződményei; 6 . selfperem, selflejtő, medence mészmárga, márga képződményei; 7. nyilt medence üledékek turbidites homokkö testekkel; 8. medenceperemi karbonátok

Figure 4. Litostratigraphy of the Palaeogene sedimentary cycles in the North Hungarian Palaeogene Basin based on TARI et al. (1993)

Legend: 1. silicious piroclastites; 2. continental coarse grained sediments, alluvial sands and gravels; 3. nearshore paralic, paludal sediments; 4. shallow marine, nearshore siliciclastic sediments; 5. open marine batial, euxin clay, silt, marl 6 . shelf edge, shelf slope, and basinal clay marl, marl sediments; 7. open marine sediments with turbidite sandstones; 8 . basin edge carbonates

Tanulmányterületünk teljes egészében az Észak-magyarországi Paleogén-medence területére esik (2. ábra), amelyen belül a legjelentősebb szerkezeti és paleogeográfiai határ a Darnó-vonal (TELEGDI RoTH 1937, ZELENKA et al. 1983). Tágabb értelemben Darnó-zónaként vagy Darnó deformációs övként (FoDOR et al. 2005, FoDOR 2010) említik a Darnó-vonalhoz köthetô szerkezetfejlődés által érintett teljes területet, mely gyakorlatilag magába foglalja a teljes Ózdi-részmedencét.

A Paleogén-medence üledékképződési modellje (4. ábra) szerint a kutatási területet csak az eocén végén, a priabonai korszakban érte el a transzgresszió, a bázisképződmények tarka és szürke, esetenként bauxitos agyagok, homok és kavics, illetve dolomittörmelék (Kosdi Formáció). A fedốben rendszerint világosszürke ún. „felsô-eocén mészkôösszlet" (Szépvölgyi Mészkő Formáció) települ. E fölött rétegtanilag a Budai Márga Formációt képviselő szürke, alsó részén nagy mennyiségú bryozoát tartalmazó, esetenként kovás mészmárga következik. BÁLDI (1983) áthalmozott andezittufa és kvarcitos-homokos tufa közberétegzéseket î́rt le bükkszéki és fedémesi mélyfúrásokból. A vizsgált terület (1.ábra d) DK-i peremén mélyült fúrásokban néhány $10 \mathrm{~m}$ vastagságban jelenik meg.

A Paleogén-medence legfontosabb, szénhidrogénföldtani szempontból is meghatározó képződményei az oligocén korú, a medence mélyebb, nyílt vízi környezeteiben lera- kódott finomszemú üledékek (Tardi Agyag, Kiscelli Agyag), a mindenkori medenceperemekhez kapcsolódó nagy porozitású homokos-kavicsos kifejlődések (Hárshegyi Homokkő, Törökbálinti Homokkő, Egri Formáció) és a nagy elterjedésû slírösszletek (Szécsényi Slír Formáció) (BÁLDI 1983).

Az Észak-magyarországi Paleogénmedence területén megjelenő képződmények közül a Budai Márga, a Tardi Agyag és a Kiscelli Agyag Formációk tekinthetôk érdemi szénhidrogén anyakőzeteknek (4., 5. ábra). Kőolaj- és alárendelten földgázgeneráló kerogént tartalmazó anyakôzetek jelentkeztek a Budai Márga felsó szakaszának meszes-agyagos (Galgamácsa, Gamcsa-1 fúrás), a Tardi Agyag agyagos-meszes (Nagykökényes. Nks-I, Gamcsa-1, Tura, Tu-5, Tu-D-1 fúrások), illetve a Kiscelli Agyag agyagos összleteiben (Tu-D-1, Tura Tu-É-2). Az oligocénnél fiatalabb képződmények jelenlegi állapotukban éretlen szénhidrogén-potenciállal rendelkezô szakaszokat tartalmaznak (Tu-D-1, Tu-D-2, Tu-É-2, Nks-I) (KósA et al. 2003, Boncz et al. 2012, 2. ábra). A legfontosabb anyakôzet a Tardi Agyag Formáció, melynek laminites felsố része szignifikánsan magasabb szervesanyag-tartalommal rendelkezik, mint az alsó, kevésbé lemezes szakasz (MiLotA et al. 1995). A képződmény elterjedése a vizsgált terület jelentős részén bizonytalan, vastagsága $28 \mathrm{db}$, a formációt harántolt medenceperemi fúrás (Bükkszék, Recsk, Mátraderecske) átlaga alapján $77 \mathrm{~m}$, de a bükkszéki fúrásokban $100 \mathrm{~m}$-t meghaladó vastagságban írták le. A Zagyva-árokban mélyült Nks-I sz. fúrás 90 méter vastagságban harántolta, 2930 és 3020 m mélységközben.

A Tardi Agyag fölött települó Kiscelli Agyag szervesanyag- és bitumentartalma jóval kevesebb. Az alig, vagy egyáltalán nem rétegzett, jellemzően bioturbált agyagmárgás aleurolit vastagsága akár az 1000 m-t is meghaladhatja (BÁLDI 1983). A Salgótarjáni-részmedence K-Ny-i tengelyétől északra (Ózd, Somoskő́ujfalu) vastagsága lényegesen kisebb (50-230 m). Szórványosan néhány méter vastag, a Tardi Agyagra emlékeztető, magasabb szervesanyag-tartalmú, lemezes közbetelepülések előfordulnak benne. BÁLDI (1983) tufás betelepüléseket is leírt Bükkszék és Eger környékéről.

A Kiscelli Agyagra a medence belsejében az egrieggenburgi Szécsényi Slír Formáció szürke, zöldesszürke, finomhomokkő közbetelepüléseivel tagolt finomhomokos, agyagos aleurolit, agyagmárga és agyag rétegsora következik, amely regionális zárókôzetként funkcionálhat. Átlagos vastagsága $340 \mathrm{~m}$, a terület északi részén meghaladja a 600 m-t (BÁLDI 1983). A Darnó-zóna közelében (pl. a Dubi- 


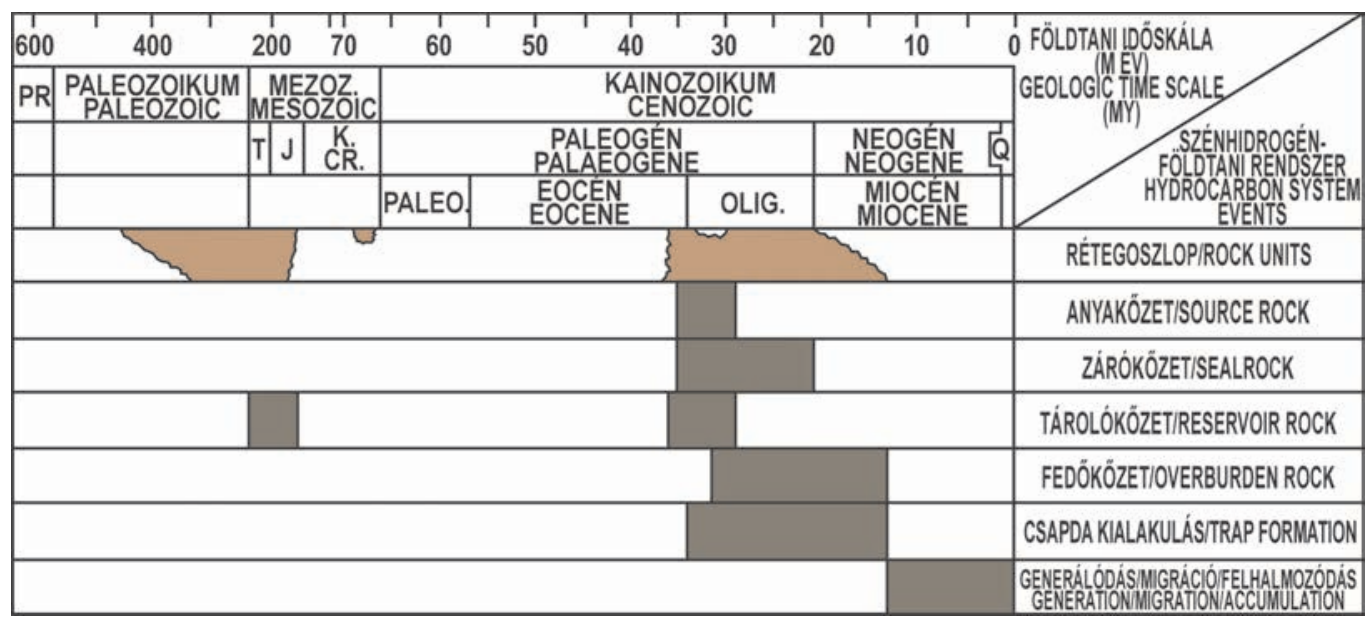

5. ábra. Az Észak-magyarországi Paleogén-medence szénhidrogén-földtani rendszerének alapelemei BABINSZKI et al. (2018) alapján Figure 5. Hydrocarbon system events chart of the North Hungarian Palaeogene Basin based on BABINSZKI et al. (2018)

csány, Du-31 fúrásban) a Kiscelli Agyagra települve a slírrel összefogazódó, Egri Formáció homokkövei is megjelennek (4. ábra). Az oligocén rétegekben megfigyelt gyúrődések utólagos deformációt jeleznek, mindezzel együtt a szerkezeti zóna oligocén aktivitását igazolják az oligomiocén üledéksorban megfigyelt gravitációs tömegmozgások (BÁLDI \& SzTANó 2000), a szerkezeti vonal két oldalának eltérô oligocén kifejlódései és a kapcsolódó szekvenciasztratigráfiai értékelések (SzTANó \& TARI 1993).

A slírre települő vagy gyakran azzal laterálisan összefogazódó Pétervásárai Homokkő Formáció ciklikus felépítésú, gyakran keresztrétegzett zöldesszürke glaukonitos homokkő, melynek vastagsága - feltehetően a lerakódását követő denudációs periódus eredményeképpen - erôsen változó (SzTANó 1994). Az Észak-magyarországi Paleogénmedence déli részén a formáció homokkövei szénhidrogén tárolókôzetek (Szócs \& HIPS 2018). Az egri-eggenburgi képződménysor üledékhézaggal települő záró üledéke a Zagyvapálfalvai Formáció csekély vastagságban települt (BÁLDI 1983, HÁMOR 1985; 4. ábra).

Az ottnangi emelet bázisán általános elterjedésú a Gyulakeszi Riolittufa Formáció (,,alsó riolittufa”). Anyaga szürkésfehér, bontottan zöldesszürke, vastagpados, biotitos, horzsaköves riolittufa, riodácit ártufa. Vastagsága a lepusztulás mértékének megfelelően 10-55 m között változik, átlagosan $48 \mathrm{~m}$. Fedőjében, illetve közvetlenül az egrieggenburgi képződmények fölött települ a Salgótarjáni Barnakőszén Formáció kezdetben limnikus, majd egyre inkább paralikus múrevaló széntelepeket tartalmazó rétegsora. A meddôt 5-10 m-es homokbetelepülések, lemezes vagy homoklencsés, széntörmelékes aleurolit, illetve közbetelepülő lumasellapadok alkotják. A formáció vastagsága 30-60 m között változik, átlagosan $45 \mathrm{~m}$. A széntelepes összletet a Nógrádi-medencében az Egyházasgergei Formáció helyenként alapkonglomerátummal települő transzgressziós homok összlete fedi (HÁMOR 1985, HÁMOR in CsászÁr szerk. 1997). A formáció azonosítására az Oncophorák megjelenése alapján a Nyugat-Borsodi-medencé- ben is van lehetôség (RADócz 1987b). Vastagsága jellemzôen 20-60 m között változik. A rátelepüló Garábi Slír Formáció uralkodóan szürke, ciklusosan változó homok, finomhomok tartalmú parttávoli - nyílt vízi aleurit, agyag, agyagmárga összlet, vastagsága átlagosan $200 \mathrm{~m}$.

A badeni emeletben induló transzgresszió nyílt vízi fáciesú üledéksora a Badeni Formáció (szürke, molluszkás agyagmárga, helyenként tufa-, tufahomok betelepülésekkel). Medenceperemi környezetben heteropikus fáciese a lithothamniumos, molluszkás, homokos, meszes Lajtai Mészkő Formáció Pécsszabolcsi Tagozata (,alsó lajtamészkô").

Az uralkodóan badeni, alárendelten szarmata neutrális magmatizmus vulkanitjait a Mátrai Formációcsoportba sorolt piroklasztikumok és lávakőzetek képviselik. Ide sorolt képződmények a terület D-i részén, a Mátra É-i előterében fordulnak eló.

A szarmata sekélytengeri, partközeli csökkent sós vízi kifejlődéseinek (Kozárdi Formáció) és a folyóvízi-tavi képződményeknek (Sajóvölgyi Formáció) elterjedése foltszerú, vastagságuk néhány $10 \mathrm{~m}$. A szarmata Galgavölgyi Riolittufa Formáció („felső riolittufa”) előfordulása a területen szórványos. A szarmata-pannóniai rétegsorba települő Dubicsányi Andezit Formáció vastagsága 10-80 m között változik. Pannóniai üledékek megjelenése nem jellemző. A negyedkorban elsősorban a völgytalpi allúviumok, illetve a lejtóüledékek halmozódtak fel. Ezek vastagsága a néhány métertől a néhány 10 m-ig változik (GYALOG et al. 2014).

\section{Alapadatok és vizsgálati módszerek}

\section{Szeizmikus adatok}

A területre 143 db különböző célú, hosszúságú és minőségú 2D reflexiós szeizmikus szelvény esik, amelyek közül a szeizmikus mélységtérkép elkészítéséhez 17 szelvény digi- 
tális mélységváltozata került értelmezésre $(\mathrm{Bu}-4,-5,-6$, Ék2, Lo-1, Oz-1, -5, -6, -7, -9, -10, -11, Ozd-1, -2, So-1, Szuha-1 és Ra-29; 1. ábra d).

Az ELGI 1986 és 1993 között végzett komplex geofizikai kutatásakor már figyelemmel voltak a medencealjzat domborzatának és kőzettani összetételének jelentős változásaira, s törekedtek a felbontóképesség növelésére, illetve a magasabb frekvenciák kiemelésére (ALBU et al. 1985, BRAUN et al. 1989, Petrovics \& Szalay 1992).

Az archivált migrált időszelvények adatait, és a hozzájuk tartozó migrációs sebességtér értékeit ProMAX rendszer alatt aktiváltuk, majd mélységtartományba transzformáltuk. A különböző években készült szelvények eltérő vonatkozási szintjeit egységesen +300 m-ben határoztuk meg. A szelvények kereszteződései alapján úgynevezett „mistie” analízist és korrekciót végeztünk. A korrekció során a medenceperemi fúrások adatait is figyelembe vettük. A Bu-6 szelvény esetében teljes újrafeldolgozás történt. melynek célja a pre-stack mélységmigráció alkalmazásával meghatározott mélységszelvény összehasonlítása a migrációs sebességterek felhasználásával végzett időmélység konvertálás által kapott mélységszelvényekkel. A Bu-6 szelvény jobb értelmezhetôségét is reméltük az újrafeldolgozástól. Az eredmények azt mutatták, hogy a mélységszelvények két különböző eljárás során csupán néhány százalék hibát mutattak. Jelentősebb különbség mutatkozott az X és Z irányú felbontóképességben a prestack migráció javára. A kapott eredmények valorizálását természetesen csak néhány célzott mélyfúrás tudná szolgáltatni. A valódi amplitúdók megôrzésére törekedő újrafeldolgozás az értelmezhetőséget némileg javította. A jelentősebb javulás korlátja a terepi paraméterek adott korban meglevő technika lehatároltsága.

Az SMT Kingdom szoftverkörnyezetben végzett értelmezés alapját 10 db, az ELGI által mért szelvény képezte, melyek a medence fő csapásirányára közel meróleges, ÉNy-DK-i lefutásúak. A medence délnyugati felében további $7 \mathrm{db}$, a MOL által méretett és az ELGI által feldolgozott Oz jelú szelvény bevonásával pontosítottuk az értelmezést. Fontos eredmény, hogy egy-egy csapásirányú szelvény (Oz-1 és -9) segítségével megtörtént a medencét keresztező, közel párhuzamosan futó hosszú ELGI-s szelvények korrelációja. Az akár több ezer méter medencekitöltő üledéksorban öt szeizmikus vezérszintet követtünk, melyek nagy amplitúdójú, markáns, az egész medencén vagy csak egyes részterületeken jól azonosítható reflexiók. A vezérhorizontok korának meghatározását és a hozzájuk rendelhető földtani képződmények azonosítását a medence belsejében szórványosan elhelyezkedő — többnyire kisebb mélységû — fúrások, illetve a medenceperemi fúrások rétegsora alapján végeztük el. Az aljzatot ért töréses szerkezeti elemek értelmezésekor azokat a vetőket jelöltük, melyek mentén lényeges szerkezeti változás történt, illetve feltétlenül szükségesek a horizont követése érdekében. A több kisebb vetôból álló szerkezeti elemek esetében a legnagyobb elmozdulást előidéző szerkezeti vonalakat jelöltük.

\section{Gravitációs adatok}

A vizsgálati terület határain belül az MBFSZ országos gravitációs adatbázisból 24736 mérési pont adatai kerültek felhasználásra a Bouguer-anomália térkép készítésekor. A szükséges korrekciók (szabad levegő, Bouguer- és topokorrekciók) elvégzése után, több korrekciós sûrúségre kiszámoltuk a komplett Bouguer-anomália értékét az MGH50 rendszerben (IGSN30, Potsdami alapszint).

Mivel a vizsgálati területen az oligocén összlet a felszínen van, és medencealjzat-kibúvásokat is találunk, így a $2400 \mathrm{~kg} / \mathrm{m}^{3}$ korrekciós sûrúséget fogadtuk el a feldolgozások során (a korrekciós súrúség értéke elvileg a tengerszint feletti összletek átlagsűrúségének felel meg). Korábbi vizsgálatok (KISs 2009, 2010) igazolták, hogy a középhegységi zónában jelentős izosztatikus hatás (kéregkivastagodás) van, ezért elvégeztük ennek a regionális hatásnak a kiszúrését (izosztatikus korrekció) a Bouguer-anomália értékekből. A további feldolgozások során ezt a korrigált térképet (6. ábra) és ennek a térképnek a szúrt változatait használtuk, tehát ez a gravitációs alaptérkép.

A gravitációs alaptérkép adatait felhasználva a „horizontális gradiens maximum eljárás" (BLAKELY \& SIMPSON 1986, CORDELL \& GRAUCH 1987, KISS 2006) segítségével hatóperem-kijelölést végeztünk, amelynek eredményeit lentebb ismertetjük A hatóperemek megadják a gradiens maximumok térképi helyét és a gradiens változásának irányából a szerkezetek vagy határfelületek csapása is meghatározható.

\section{A prekainozoos mélységtérkép szerkesztéséhez. felhasznált adatok}

A fent említett szeizmikus és gravitációs mérési adatok, ill. a területen mélyült fúrások adatai alapján került sor az egységes szemléletû medencealjzat-térkép készítésére, illetve a medenceüledékek jellemző horizontjainak meghatározására. Az aljzat szintvonalait a hazai medenceterületre szerkesztettuik meg, ahol a szeizmikus értelmezésből származó adatok is rendelkezésre álltak. Természetes határt jelentenek az Aggtelek-Rudabányai-hegység, az Upponyi-hegység, a Bükk, a Darnó-hegy paleo-mezozoos alaphegységének felszíni kibúvásai (1. ábra). NyDNy-i és KDK-i irányban a medencealjzat szintvonalainak elvégeztetése a feldolgozott alapadatok függvényében történő döntés eredményeképpen alakult ki. A szerkesztés során elsőrendű adatként szolgáltak az alaphegységet elérô fúrások (1. ábra d), ill. az értelmezett szeizmikus reflexiós mélységszelvények aljzatként értékelt horizontjainak mélységadatai.

Azokon a területrészeken, ahol nem állt rendelkezésre mélyfúrási és szeizmikus adat, a gravitációs mérések adatainak (6. ábra) lentebb bemutatandó, különböző feldolgozású térképi megjelenítéseit használtuk fel. Kisebb medenceperemi szakaszokon figyelembe vettük archív szkennelt és digitalizált szeizmikus reflexiós, refrakciós és geoelektromos térképek szintvonal adatait is (SZALAY 1971, 1976; SzALAY \& Albu 1986; SzAlay et al. 1987, 1988). Tájékoztató adatként vettük figyelembe az archív magnetotellurikus és gra- 


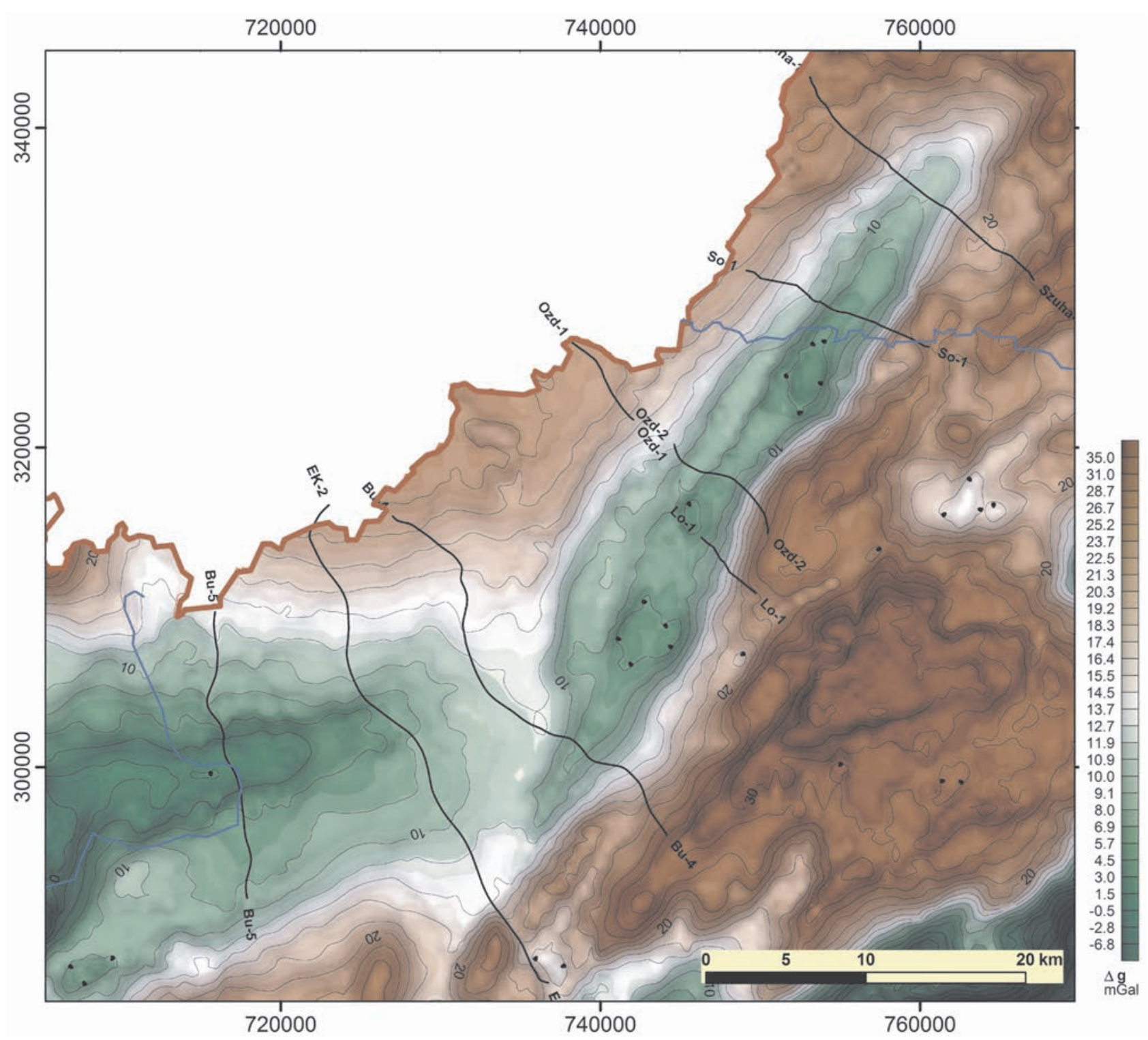

6. ábra. Izosztatikusan korrigált, $2400 \mathrm{~kg} / \mathrm{m}^{3}$ korrekciós sủrűséggel kiszámolt Bouguer-anomália térkép

Figure 6. Isostatically corrected Bouguer anomaly map counted with $2400 \mathrm{~kg} / \mathrm{m}^{3}$ reduction density

vitációs maradékanomália-térképeket, ill. a kéziratos refrakciós szelvényeket (MADARASI 1990, KovÁCSVÖLGYI \& SCHÖNVISZKY 1991).

\section{Eredmények és értelmezésük}

\section{A szeizmikus értelmezés eredményei}

A medence belső területén kevés az aljzatot ért mélyfúrás (1. ábra d). A szeizmikus értelmezés segítéséhez ezért viszonylag távolról bevetített — általában $1 \mathrm{~km}$ távolságon belüli - fúrási rétegsorokat használtunk, melyek főként a fedő üledékekről szolgáltattak geológiai információt. Az 1986 és 1993 közt mért ELGI szerkezetkutató szelvényeket a nagy mélységben elhelyezkedő medencealjzat megismerésére tervezték. Ennek megfelelően a szelvényeken jel- lemzően a legnagyobb amplitúdójú jelcsomagok értelmezhetôk a medencealjzat lekoptatott felszíneként. Ezt az elgondolást a néhány aljzatot ért mélyfúrás jó közelítéssel alátámasztja (pl. a Bükkszék Bu-Ny-2 az Ék-2 szelvényen [2., 7. ábra], a Lénárddaróc Ld-2 a Lo-1 szelvényen, a Susa-1 az Ozd-1 szelvényen, a Serényfalva Sf-2 a So-1 szelvényen (8. ábra), az Alsószuha Asz-1 és a Jánkfalva J28 a Szuha-1 szelvényen). A medencealjzatot általában nem egy reflexió, hanem több fázispárból álló reflexiócsomag jelöli, ez esetben a köteg tetejét jelző elsô pozitív jelen értelmeztük a réteghatárt (8. ábra). A maximális amplitúdójú jelek korrelálásán túl a medencealjzat azonosítását segítették az eróziós lenyesési felülethez köthető — az aljzat belsejének szerkezetét kirajzoló fellapolódó reflexióelvégződések (ún. toplap felszín vagy eróziós lenyesési felület), illetve a medencét feltöltő üledék reflexióinak esetenkénti rálapolódásának (downlap felszín), valamint kiékelődésé- 


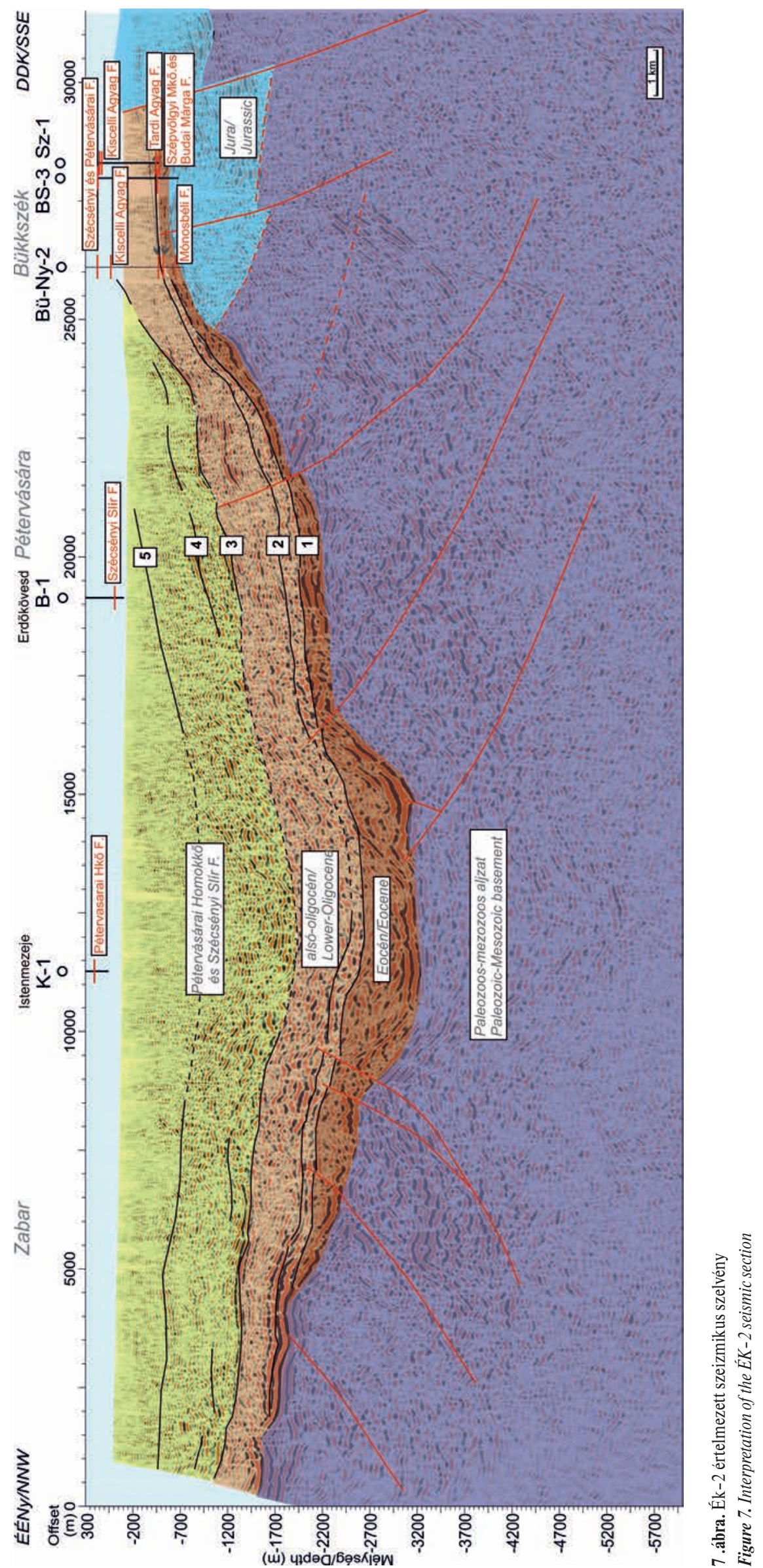




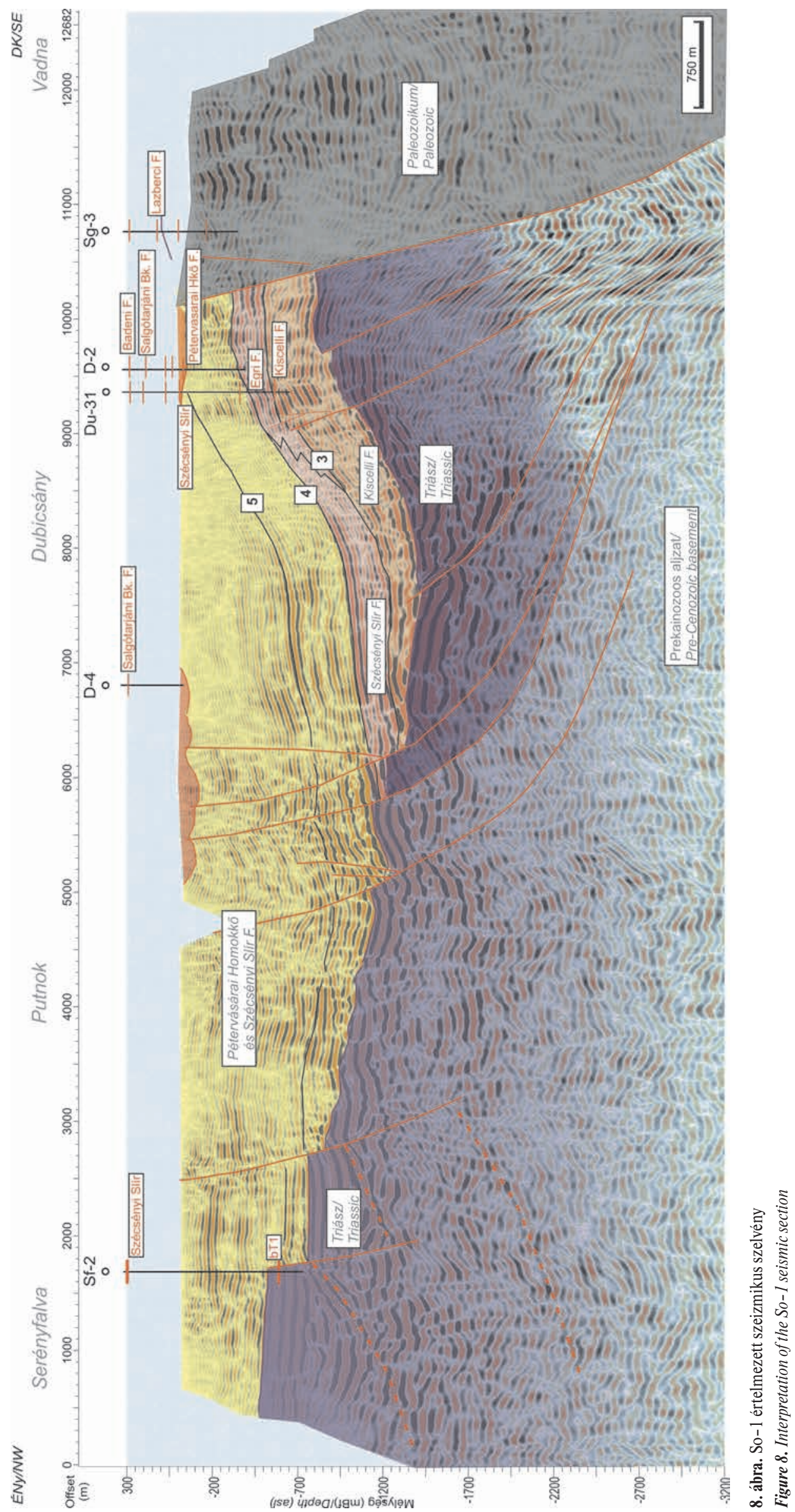


nek követése. A medencealjat értelmezésekor nem tettünk különbséget a feküképződmények földtani kora és kőzetminősége között, egységesen prekainozoos aljzatként kezeltük. Ennek eredményeként készült el az a szeizmikus mélységtérkép, mely a peremi, Darnó-zónától keletre esô felszíni kibúvásoktól (kb. 200-300 m tszf.) a legmélyebb részeken -3400 mBf-ig terjed (9. ábra)

A paleogén medencekitöltésben értelmezett öt vezérszint korolását a szórványosan elhelyezkedő, többnyire a medence peremén csoportosuló fúrások csak részben oldották meg. A mélymedencerészeken nagyobb bizonytalanságú az 1-es és a 2-es szint korbeosztása.

1. Eocén horizont: a prekainozoos aljzat felett települő, erősen változó vastagságú, a mélymedence felé kivastagodó, heterogén szeizmikus fáciesű képződmények tetőszintje. Az összlet alján a változó folytonosságú jelcsomag általában az aljzathoz nagyon hasonlóan nagy amplitúdó- jú, és gyakorta az aljzattal teljesen konform módon települ. A mélymedencerészen ezekre gyakran kaotikus fáciesú, helyenként közepes-gyenge folytonosságú, a medence belseje felé dőlő reflexiókkal jellemzett szeizmikus fáciesû́ rész következik. Az 1-es szint által határolt szeizmikus egység a peremek felé elvékonyodik, helyenként felismerhetô a kiékelődésre jellemzô rálapolódó reflexió elvégződés is. A peremi fúrásokban az összevontan kezelt eocén Szépvölgyi Mészkő és Budai Márga Formációval (4. ábra) korrelál. A heterogén szeizmikus fácies az eltérő kőzetminőséggel magyarázható, ahol az erős, nagy amplitúdójú jelek dominálnak, a Szépvölgyi Mészkô, illetve a Budai Márga mészkő betelepüléseinek megjelenését valószínúsíthetjük. A kaotikus fácies nagy vastagságú törmelékes összlet jelenlétére utalhat.

2. Tardi Agyag horizont: a Salgótarjáni-részmedencében megjelenő, kisebb-nagyobb folytonossággal követhető,

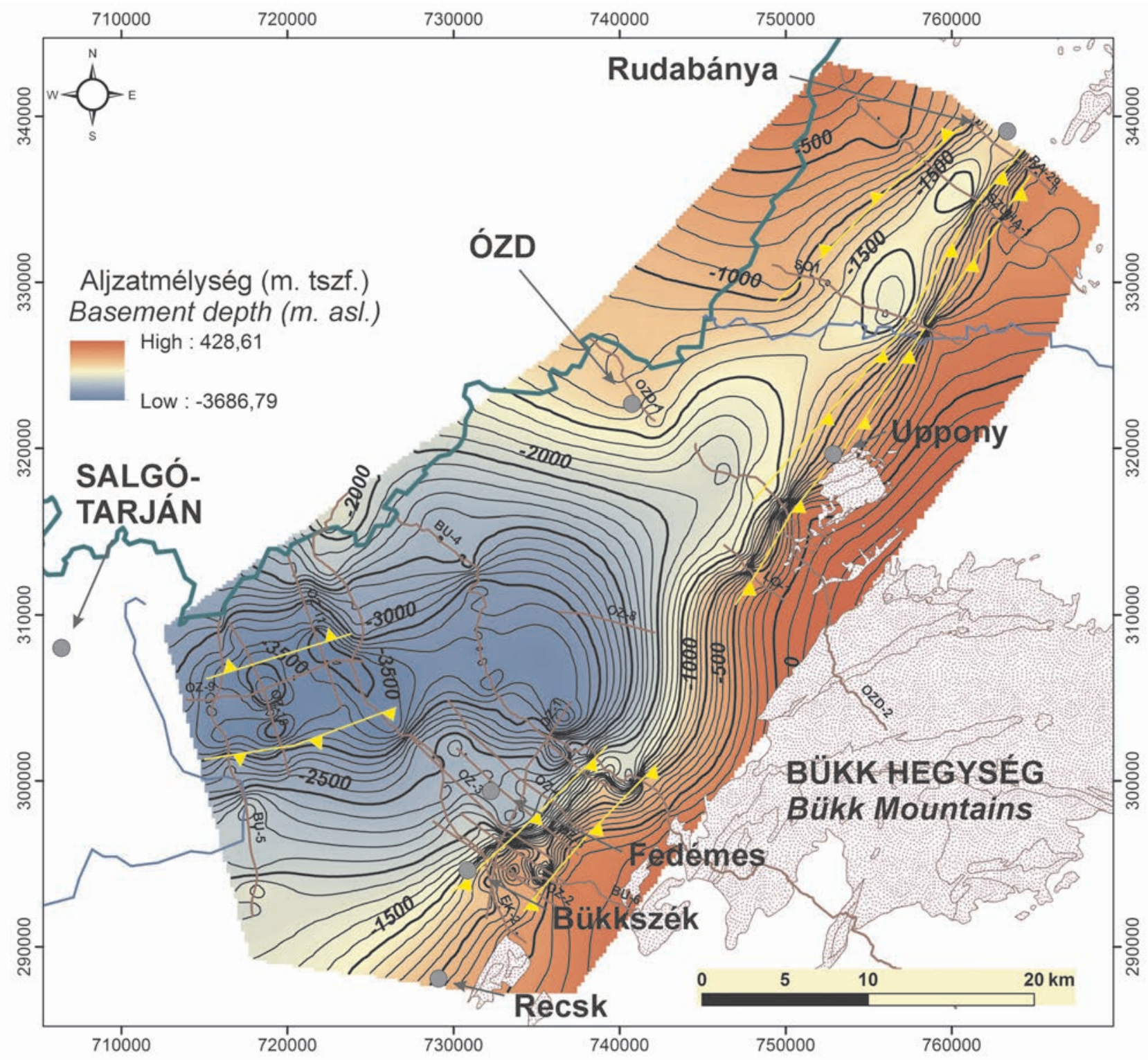

9. ábra. A medence prekainozoos aljzatának mélységtérképe a szeizmikus értelmezés alapján. A mélységértékek tengerszinthez viszonyított értékeket jelölnek Figure 9. Pre-Cenozoic basin basement depth map based on seismic interpretation (depth values referred to sea level) 
változó amplitúdójú határfelület, mely a medence peremein helyenként kiékelődik. A délkeleti medenceperemen a szint a bükkszéki és fedémesi szerkezetek fúrásaiban jó közelítéssel a Tardi Agyag Formáció tetőszintjével korrelálható, mely a medence mélyebb részeire is továbbvihetô. A peremeken a képződmény vastagsága a szeizmikus felbontóképesség határán van, így itt csak hipotetikusan — a fúrások alapján értelmeztuik. A mélyebb részeken 1-3 reflexió is tartozhat hozzá. Az egységben helyenként megjelenő nagy amplitúdójú jelek a Tardi Agyagba települó mészturbiditekkel (VARGA 1982) hozhatók összefüggésbe.

3. Kiscelli horizont: Az Ózdi- és a Salgótarjáni-részmedencében is jól követhető szint, a fedô üledékes rétegsorban viszonylag jó folytonosságú, nagy amplitúdójú jelekkel mutatkozik. Lefutása az Ék-2 szelvényen (7. ábra) jól kirajzolja a medencerész enyhén aszimmetrikus alakját. A So-1 szelvény mentén (8. ábra), illetve az Ózdi-részmedencében csak a délkeleti részen nyomozható. A peremi területek fúrásaival is jól korrelálható szint a Salgótarjáni-részmedencében többnyire nagy, míg az Ózdi-részmedencében csekélyebb vastagságban megjelenô Kiscelli Agyag tetôszintje.

4. Felsô-oligocén horizont: jó folytonosságú, nagy amplitúdójú reflexió, azonban fúrásokkal való korrelációja bizonytalan. A So-1 szelvény mentén a Dubicsány Du-31 fúrás alapján az Egri Formáció egyik markáns szintjével vagy tetőszintjével eshet egybe. A jól dokumentált (BÁLDI \& SZTANó 2000) fúrás alapján a peremi részeken eróziós szintként jelentkező felület, mely a medence mélyebb részei felé unkonformitásba megy át, az egri képződményeken belül jelentkező intraegri denudációt, ez esetben az oligocén és miocén képződmények határát is jelezheti. Alternatív értelmezése lehet a helyenként diszkordánsan települő Szécsényi Slír Formáció talpa is.

5. Alsó-miocén horizont: többé-kevésbé jó folytonossággal követhetô közepes amplitúdójú, a fekü üledékekkel konform módon kirajzolódó reflexió a Szécsényi Slír és Pétervásárai Homokkố szintjeiben. Az Ózdi-medencerészben jól nyomozható, szépen kirajzolja a medencerész aszimmetrikus alakját.

A szeizmikus értelmezés alátámasztotta azt a korábbi elgondolást, hogy az Ózdi- és a Salgótarjáni-részmedence mind az aljzat mélysége, mind a medencét kitöltő üledékrétegsor tekintetében eltérést mutat. Ezért a továbbiakban érdemes a két részt külön tárgyalni. Ennek megfelelően a két medencerészben a fedô rétegsor csak részben mutat átfedést.

Az Ózdi-részmedence sekélyebb (8., 9. ábra), és a fúrások tanúsága szerint kitöltése fiatalabb, mint a Salgótarjánirészmedencéé (7. ábra). A Kiscelli Agyag Formáció kisebb vastagságban jelenik meg, az ennél idősebb oligocén képzôdmények jelenlétére nincs bizonyíték (Less et al. 2006). A kiscelli emelet képződményeire többnyire Szécsényi Slír települ, vagy a peremi területeken az Egri Formáció is megjelenik lokálisan (Du-31 fúrás, BÁLDI \& SZTANó 2000). A Szécsényi Slír felett vagy azzal összefogazódva a Pétervásárai Homokkő Formáció képződményei (4. ábra) is nagy vastagságban jelennek meg, bár szeizmikus fáciesük alapján nem lehet ôket a szelvények mentén elkülöníteni. A részme- dence csapása a Darnó-zónával megegyező, ÉK-DNy-i. A szelvények és a fúrások tanúsága szerint délnyugat felé mélyül, a mélymedencék aljzata -900 mBf-tôl -1600 mBf. mélységig süllyed (9. ábra). A részmedence szerkezete aszimmetrikus, északnyugati szárnya laposabban dől, mint a délkeleti, ami jó összhangban van a SzTANó \& TARI (1993) által interpretált eredményekkel. A részmedence keleti határát a Darnó-vonal jelenti. A szelvényeken jól látható a medencealjzat Darnó-vonal mentén több lépcső́ben bekövetkezó emelkedése, és a kapcsolódó ÉNy-i vergenciájú feltolódások sora (FoDOR et al. 2005, FoDOR 2010). A So-1 szelvény (8. ábra) ugyan nem képezi le, de jól ismert a Darnó-vonal miocén korú normálvetős felújulása a területen (SCHRÉTER 1951, 3. ábra). A medencerész északnyugati szárnyának aljzatában délkeleti vergenciájú áttolódási síkok ismerhetők fel, amelyek beilleszthetők TARI et al. (1993) flexurális medencefejlódési modelljébe. Ezeket azonban helyenként a feltételezhetôen szinrift miocén extenzióhoz tartozó normálvető́k (FoDOR 2010, PETRIK et al. 2016) felülírják, melyek kora azonban a szelvények alapján egyértelmúen nem állapítható meg.

A Salgótarjáni-részmedence jelentősen mélyebb, jóval $-3000 \mathrm{mBf}$ alá mélyül. A részmedence kiszélesedik, és csapása KÉK-NyDNy-ivá válik (9. ábra). A medence két peremén ellentétes vergenciájú feltolódások értelmezhetők, hasonlóan az Ózdi-medencerészhez, azonban itt a délies vergenciájú szerkezeti elemek markánsabban jelennek meg. A Darnó-zóna elôterében megjelenő északias vergenciájú feltolódások déli irányban egyre meredekebbé válnak. A medence középső része sajnos kevéssé jól értelmezhetô a jel/zaj arány lecsökkenése miatt.

A mélyebb medencerészek alsó-oligocén üledékekkel vannak kitöltve, melyek alatt az aljzatra települve felső-eocén üledékek is korrelálhatók. Az eocén üledékek vastagsága átlagosan 200-220 m körüli, nyugat felé kivastagszik, míg a kiemelt bükkszéki és fedémesi szerkezeteken elvékonyodik néhány 10 m-re, és többnyire ki is ékelődik (7.ábra). Az alsóoligocén képző́dmények vastagsága is változó. A délkeleti peremen a fúrások tanúsága szerint $500-650 \mathrm{~m}$, ami a medence mély részein akár az 1000 m-t is elérheti. Az északnyugati peremen vastagsága ismét lecsökken $300-500 \mathrm{~m}$-re, amely összhangban van a szlovák oldalon közölt adatokkal (VAss et al. 1989). A Tardi Agyag Formáció csak a Salgótarjáni-részmedencében jelenik meg, a peremi fúrásokban 50210 m közt változó vastagságban írták le (Bü-Ny-2, Bs-3). A medencekitöltés közel felét feltételezhetően itt is a felszínen megjelenő Szécsényi Slír és Pétervásárai Homokkő Formáció képződményei teszik ki, bár ebben a medencerészben nem találhatók olyan fúrások, amelyek néhány száz méternél nagyobb vastagságban harántolták e képződményeket (a kis mélységú fúrások többnyire nem fúrták át).

\section{A gravitációs feldolgozás eredményei}

Mivel a nehézségi erôtér összegzett hatást mutat, a gravitációs hatóperemek (10. ábra a) is a legerősebb, domináns hatásokat jelzik elsősorban. Az eljárás a felszínközeli, nagy 


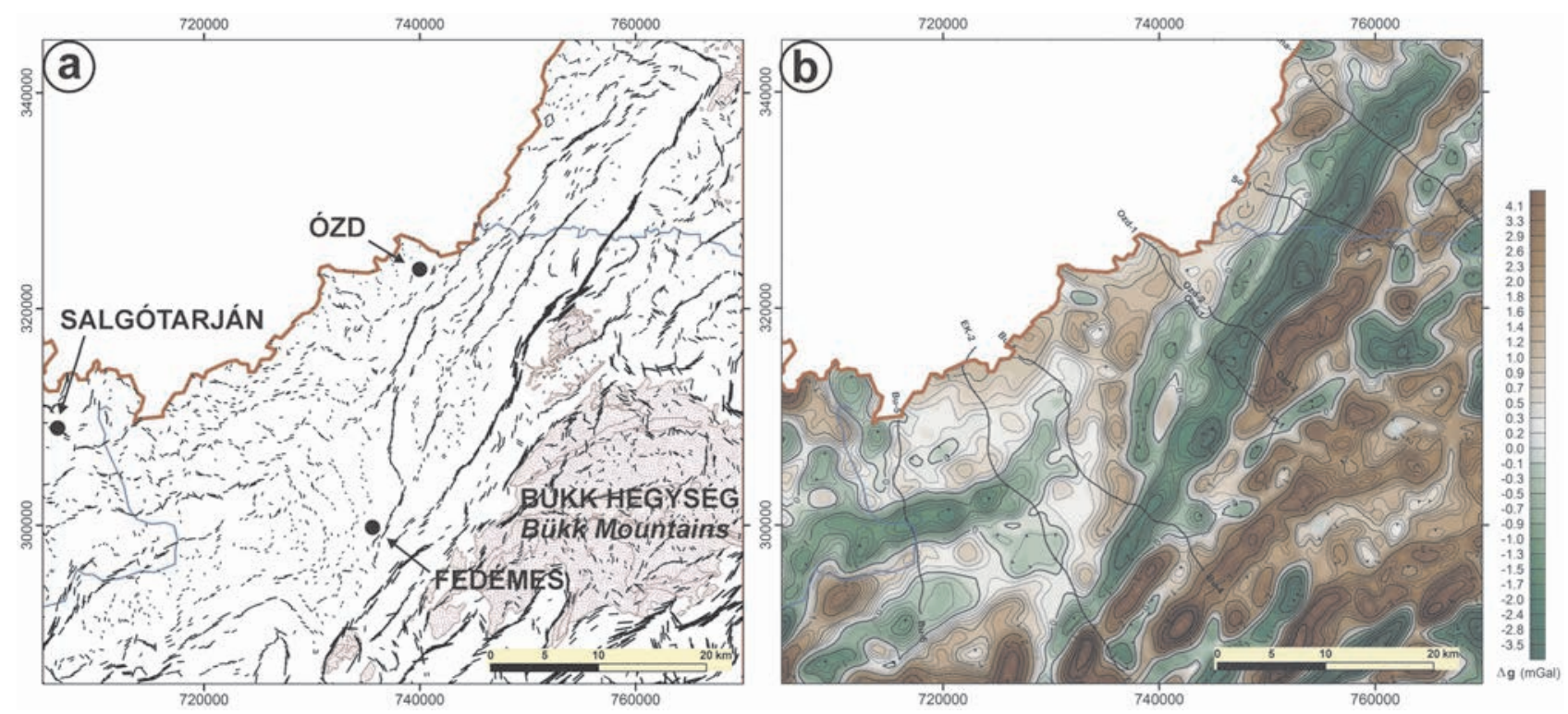

10. ábra. Gravitációs hatóperemek térképe (a) és az 1600 m mélységủ hatások Bouguer-anomália térképe a korrelációhoz felhasznált szeizmikus szelvények nyomvonalával (b)

Figure 10. Edge detection map based on the horizontal gradient of gravity - sharpen the geological changes, as different lithology, faults (a) and Bouguer-anomaly map filtered to the effects from $1600 \mathrm{~m} \mathrm{bsl}(\mathrm{b}$ )

gradienssel jelentkező változásokra a legérzékenyebb, így azok hatása látszik legjobban. A mélyebb hatások is jelen vannak, de azok kevésbé karakterisztikusan jelentkeznek. A hatóperemek jelzik az egyes kifejlődési területek határát, illetve a kisebb részmedencék elterjedési területét, azaz a szerkezeti határok legvalószínúbb helyét.

A hatóperemek és a különböző földtani térképek összevetése mutatja a szerkezeti kapcsolat erősségét, és mivel a terület ilyen jellegú vizsgálatát most először végeztük el, jelezheti a hiányzó (eddig ismeretlen) szerkezeti vonalak helyzetét is.

A hatóperemek fô iránya a Salgótarjáni-részmedencében, a Mátrától É-ra, NyDNy-KÉK-i. A hatóperemek Fedémestôl északra, Ózd felé jeleznek egy közel É-D-i szerkezetet, ami egy Ny-i és egy ÉK-i részre választja ketté a vizsgált területet. A gravitációs hatóperemek ettôl a szerkezettől ÉKre már a Darnó-zóna szerkezeti irányaival párhuzamosak (10. ábra a). Ez az elem szerepel Less et al. (2004) térképén, sôt már korábbi (JASKó 1946, BALOGH 1964) térképeken is megjelenik. A gravitációs adatok tehát alátámasztják a korábbi terepi észleléseket, és kiemelik a szerkezet fontosságát.

A foobb gravitációs hatók mélységének meghatározása céljából spektrális mélységszeletelést végeztünk (CORDELL 1985, KISs 2014). Ezen a területen három különböző szintet (325 méter, 1600 méter, 7000 méter) és azok gravitációs hatását különítettük el. A medencealjzat-mélységtérkép szerkesztéséhez az 1600 m-es szint (10. ábra b) a területen lévő medencék mélységével összevethető mélység, ezért fontos szerepe volt a feldolgozások során. Ezen a térképen rajzolódnak ki a medenceterületek részmedencéi, sajátos gerincvonalakkal elválasztva, aminek eredete további elemzés tárgyát képezi. A hatóperemek alapján kirajzolódó É-D-i elválasztó vonal Fedémesnél önálló, aszimmetrikus gerincvo- nulatként jelenik meg a szúrt térképen, elválasztva a Ny-i (Salgótarjáni-részmedence) és az ÉK-i (Ózdi-részmedence) kifejlődési területet.

A paleogén medence kevés mélyfúrási adata miatt a szeizmikus szelvényeken (Bu-4, -5, Ék-2, Ozd-1, -2, Lo-1, So-1, Szuha-1, Ra-29) értelmezett prekainozoos aljzat szintjét használtuk a gravitációs mélységtérkép elkészítéséhez. Elsőként a medencealjzat szintjének (mBf) és a 2400 $\mathrm{kg} / \mathrm{m}^{3}$ korrekciós sûrúséggel kiszámolt és a Moho-szinttel korrigált Bouguer-anomália adatok kapcsolatát vizsgáltuk (11. ábra a).

A szeizmikus értelmezésből adódó medencealjzat-szintek és a gravitációs mérésekből származó Bouguer-anomália adatai között a vizsgálati terület egészére nézve nincs egyértelmú kapcsolat. Egy adott gravitációs értékhez jó esetben egy, de többnyire két mélységadat is kapcsolódik, ami nyilvánvalóan arra utal, hogy földtani felépítés szempontjából legalább kétféle földtani modellel kell számolni. A vizsgálat eredménye szerint, a 11. ábra a részén piros, illetve világosbarna egyenessel jelölt két különböző trend két különböző (szeizmikus-gravitációs) modellt jelez.

Az ÉK-i szelvények (Lo-1, So-1, Szuha-1, Ra-29) ese-

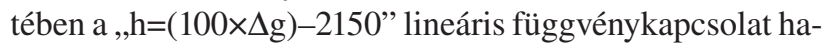
tározható meg (I., ÉK-i blokk, 11. ábra b). A Ny-i szelvények (Bu-4, -5, Ék-2) esetében azonban a korábbi összefüggés csak a szelvények D-i részére igaz, a szelvények É-i részen egy teljesen más kapcsolat rajzolódik ki. Itt a

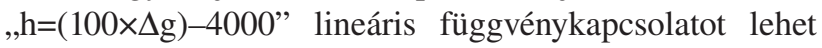
meghatározni (II., Ny-i blokk, 11. ábra b).

Ezek szerint a medencealjzat mélységmeghatározását a két részterületen elkülönítve kell elvégezni, majd vizsgálni a két terület közötti kapcsolódást.

A lineáris függvénykapcsolat hasonlóságából az olvas- 

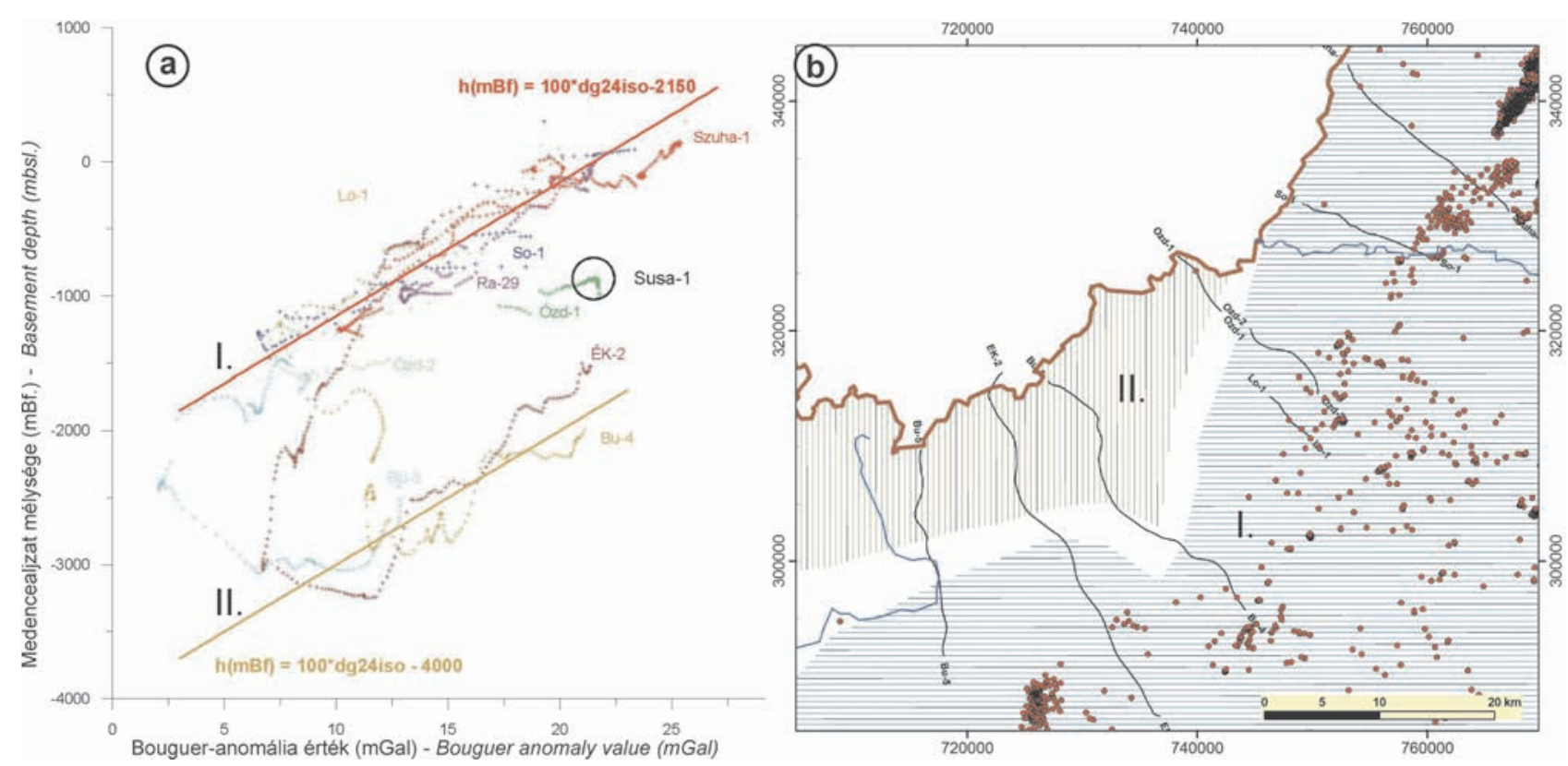

11. ábra. Szeizmikus medencealjzat-mélység és izosztatikusan korrigált Bouguer-anomália ( $2400 \mathrm{~kg} / \mathrm{m}^{3} \mathrm{korrekciós} \mathrm{sűrűség,} \mathrm{a} \mathrm{képletben} \mathrm{dg24iso)} \mathrm{értékek}$ kapcsolata (minden szelvény adata eltérő színnel megjelenítve) (a); és a terület blokkosítása a felhasznált szeizmikus szelvények mentén kapott aljzatmélységek és a gravitációs mérési adatok alapján (b) (vízszintes sraffozás: I., ÉK-i modell/blokk), függőleges sraffozás: II., Ny-i modell/blokk), köztes fehér terület: váltás és árokvonal)

Figure 11. Connection between the intepreted seismic basement depth and the isostatically corrected Bouguer anomaly data (dg24iso in the equation - correction density: $2400 \mathrm{~kg} / \mathrm{m}^{3}$, every $2 \mathrm{D}$ seismic line with different colour) (a); and the different blocks of the area based on integrated interpretation of the seismic basement depth and the gravity data - with the lines of seismic sections used to integrated interpretation (b) (horizontal hatching: I., north-eastern model/blokk, vertical hatching: II., western model/block, intermedier white area: transitional zone

ható ki, hogy ugyanazt a Bouguer-értéket egy kb. 1850 m-rel mélyebben található, jóval nagyobb sưrúségú medencealjzat-képződmény is létrehozhatta a területen. Ez arra utal, hogy jelentős eltérés van a mélybeli felépítésben a két terület között. Ráadásul a két sûrűségmodell között még egy átmeneti zónának is kell lennie, mivel a szeizmikus szelvényeken is folyamatos a medencealjzat lefutása (nincsenek jelentős ugrások).

Figyelembe kell venni, hogy a medencealjzat szeizmikus értelmezésénél nem tettünk különbséget a feküképződmények földtani kora és kőzetminősége között (azaz sûrúsége között sem), egységesen prekainozoos aljzatként kezeltük őket. A gravitációval való összevetés azonban jelzi, hogy különböző feküképződményekrôl van szó. A kérdéses területrészen azonban nincs olyan fúrás, ami alapján az eltérô feküképződményeket pontosan azonosítani lehetne. Mivel a gravitáció összegzett hatást mutat, így akár a fedőben bekövetkezô változás is hatással lehet a Bouguer-anomália értékére.

Az Ozd-1 és Ozd-2 szelvények az átmeneti zónába tartoznak — a Susa-1 mélyfúrással együtt, bár az Ozd-2 jelentôs része még az ÉK-i blokk menetét mutatja. A 11. ábra b alapján az is látszik, hogy a Ny-i blokkban gyakorlatilag nincsen mélyfúrásból származó közvetlen mélységadatunk, ami bizonytalanná teszi az értelmezést.

A terület mélységtérképének összeállításakor a következő típusterületekkel kellett számolni:

Kibúvás területek, itt a medencealjzat mélysége a felszíni domborzat magassága lesz;

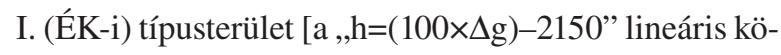
zelítéssel];

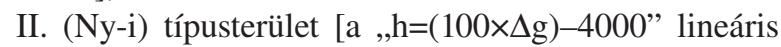
közelítéssel];

Átmeneti zóna a két típusterület között bizonytalan szélességgel.

A mélységtérkép szerkesztése során tehát a kibúvásos területeken a domborzat magasságértékeivel számoltunk, az átmeneti területeket pedig üresen hagytuk. Így az ÉK-i blokk, a Ny-i blokk és a kibúvások szintjeiből képeztünk egy adatrendszert, amiből „minimum curvature” eljárással 500 m-es gridet interpoláltunk az egész területre (12. ábra).

A kutatási területen tehát két medencerész találkozik, a Salgótarjáni-részmedence Ny-on és az Ózdi-részmedence ÉK-en, amelyre a gravitációs Bouguer-anomália térkép (6. ábra) és a hatóperemek (10. ábra a) hívják fel a figyelmet. A feldolgozások alapján a medencék közötti közel É-D irányú határvonal a típusterületi modellek határvonala is egyben.

\section{A prekainozoos aljzatmélységtérkép}

A szeizmikus mélységtérkép adatait a gravitációs mélységtérkép adataival kiegészítve, ill. archív medenceperemi geoelektromos és szeizmikus térképek figyelmbe vételével készült el a korrigált prekainozoos aljzatmélységtérkép (13. ábra). Az aljzatfeluilet reális ábrázolása érdekében szuikség volt az aljzat markáns szerkezeti elemeinek ábrázolására, melyhez elsôsorban a gravitációs hatóperemtérkép (10. ábra a) és szeizmikus értelmezés (9. ábra) nyújtott segít- 


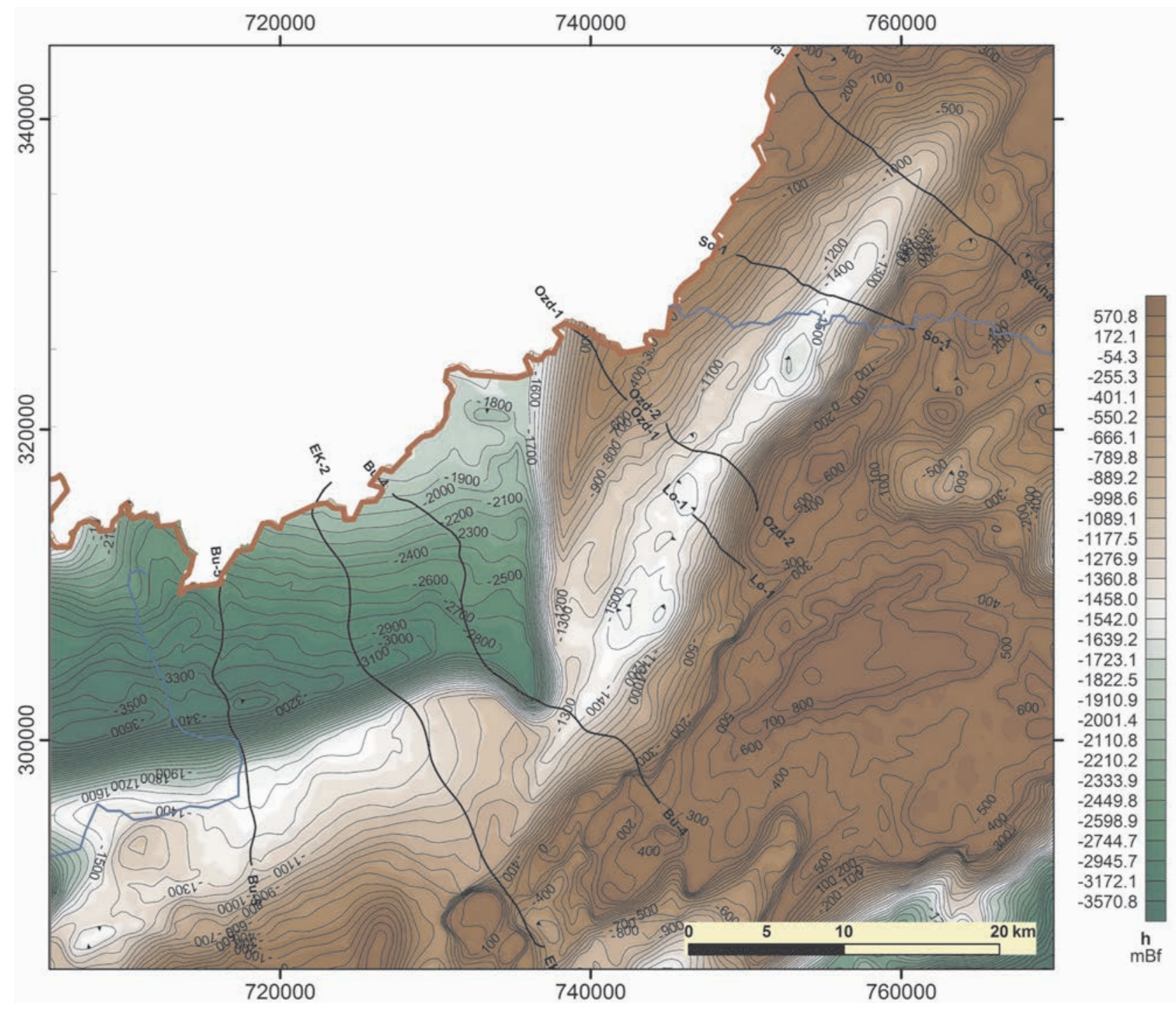

12. ábra. Az aljzat gravitációs mélységtérképe (mBf.) a szeizmikus adatokkal való vonalmenti korreláció alapján

Figure 12. Gravity basement depth map based on the correlation with seismic data along the interpreted lines

séget. A gravitációs mélységtérkép adatait a mélymedencerészeken vettük figyelembe egyéb adat hiányában. A szintvonalak a térinformatikai program szerkesztési lehetôségeit kihasználva manuálisan, a magassági pontok és a háttér szintvonalas megjelenítései között észszerúen korrigálva kerültek megrajzolásra, a szintvonalköz 100 méter.

A térkép (13. ábra) két, egymástól élesen el nem határolható medencerészt mutat. Az 1100-2000 m tszf. aljzatmélységú, ÉK-DNy-i tengelyú Ózdi-részmedence az azt KDKről határoló, medenceperemi Darnó-vető mentén húzódik. Az aljzat a vetố menti közel 0 méter tszf. magasságtól ÉNy felé 3-5 km-re már eléri a helyi legnagyobb mélységét, majd enyhébben emelkedik tovább. A medencerész aljzatának DK-i oldalában a szeizmikus szelvények alapján ÉNy-i vergenciájú feltolódások észlelhetốk, a medence ÉNy-i oldalában szintén feltolódásos, de ellenkezô vergenciájú feltolódások sorozata észlehetô. A szeizmikus szelvények közötti területen ezek a szerkezeti elemek nehezen korrelálhatók. A térképen jelzett szerkezeti elemek megjelenítése során ezért a gravitációs hatóperemek térképére is támaszkodtunk. Az Ózdi-részmedence északi és középsô részén az Észak-magyarországi Paleogén-medence érdemi anyakőzetei közül a szeizmikus értelmezés alapján a Kiscelli Agyag Formáció van meg, de a medence mélysége, és az alább részletezett szénhidrogén-földtani adatok alapján feltehetôen sem ez, sem fedőképződményei nem jutottak el a kőolajképződés zónájába.

A Salgótarjáni-részmedence az Ózdtól dél felé húzódó aljzati gerinc nyugati-délnyugati részén, a Darnó-vetó Bükkszék környéki vonalától ÉNy-ra mélyül, és a DK-i medenceperemtôl ÉNy felé mintegy 16-20 km-re éri el -3400 méterben (tszf.) legnagyobb mélységét. Az itt mért szeizmikus vonalak értelmezése szerint a medencerész tengelye ÉK-DNy-i irányítottságú, közepén DK-i irányba megtörik. A medencealjzatban megjelenô vetők a medence ÉNy-i oldalában DK-i vergenciájú feltolódások, a medence mélyzónájától délkeletre pedig ÉNy-i vergenciájú feltolódások. A medencében értelmezett várható anyakőzet összletek, és a 


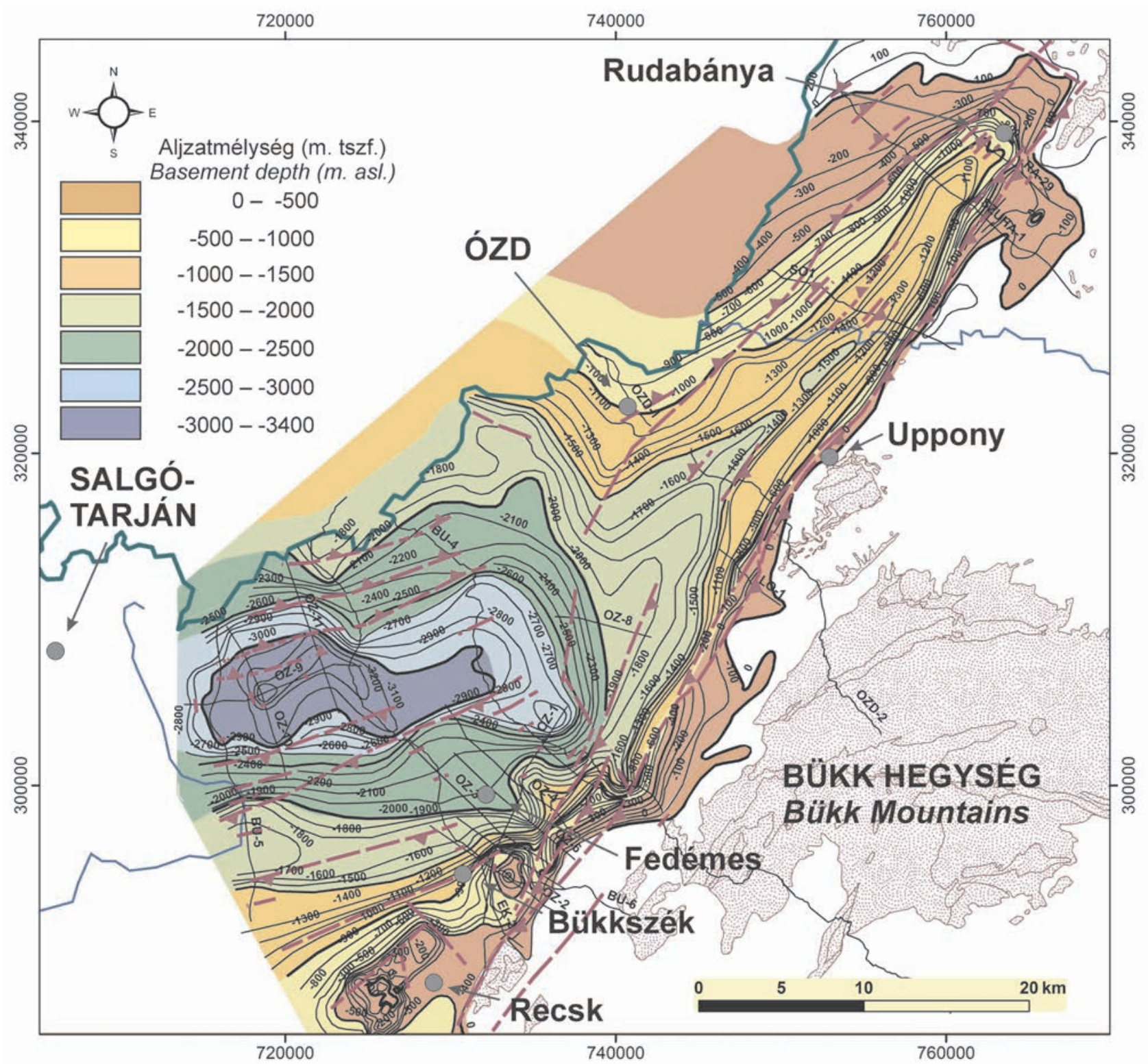

13. ábra. A vizsgált terület prekainozoos aljzattérképe az értelmezett és a feltételezett szerkezeti vonalakkal (szaggatott lila)

Figure 13. The pre-Cenozoic basin basement map with interpreted and supposed structural lines (dashed purple)

medence kiterjedése alapján ez a medencerész produktív szénhidrogén képződés és felhalmozódás szempontjából.

Az elkészült aljzattérkép szintvonal és szerkezeti vonal ábrázolását összehasonlítottuk korábban készült medencealjzat mélységtérképekkel, illetve különböző korábban készült földtani térképek szerkezeti vonal megjelenítéseivel. A 100 méter szintvonalközú részmedencetérképünk az országos léptékú ábrázolásoknál (TANÁCS \& RÁLISCH 1990, KILÉNYI et al. 1991, HAAs et al. 2010; 1. ábra $a, b, c)$ az aljzatdomborzatnak nyilván részletesebb, jobb felbontású megjelenítését nyújtja. Lényegi különbség a két részmedencét elválasztó, Ózdtól délre megjelenő gerinc, a fedémesi, bükkszéki, recski magaslatok elkülönült megjelenése, illetve a Salgótarjánirészmedence mélyzónájának részletgazdag rajzolata, amely a szénhidrogén-kutatás szempontjából is informatív.
Két térképrészlet (14. ábra) mutatja be a munkánk során készült gravitációs hatóperem térkép (11. ábra a) vonalainak, illetve a medencealjzat-térképen (13. ábra) szereplő szerkezeti vonalaknak a lefutását a vizsgált terület felszíni földtani térképére (GYALOG et al. 2014) és prekainozoos aljzattérképére (HAAS et al. 2010) vetítve. Mind a gravitációs hatóperemek sorozatai, mind az új aljzattérképen szereplő szerkezeti vonalak jó összhangban vannak a földtani térképeken ábrázolt vonalakkal, illetve az Ózdi-részmedencét tekintve korábban készült földtani térképeken, ábrákon bemutatott szerkezeti vonalassággal (pl. BALOGH 1964, RADÓCZ 1966, ZELENKA et al. 1983, JASKÓ 1989, LeSS et al. 2004, FODOR et al. 2005).

A Salgótarjáni-részmedence esetében mind a hatóperemek, mind a szerkezeti vonalak lefutása rávilágít eddig nem 

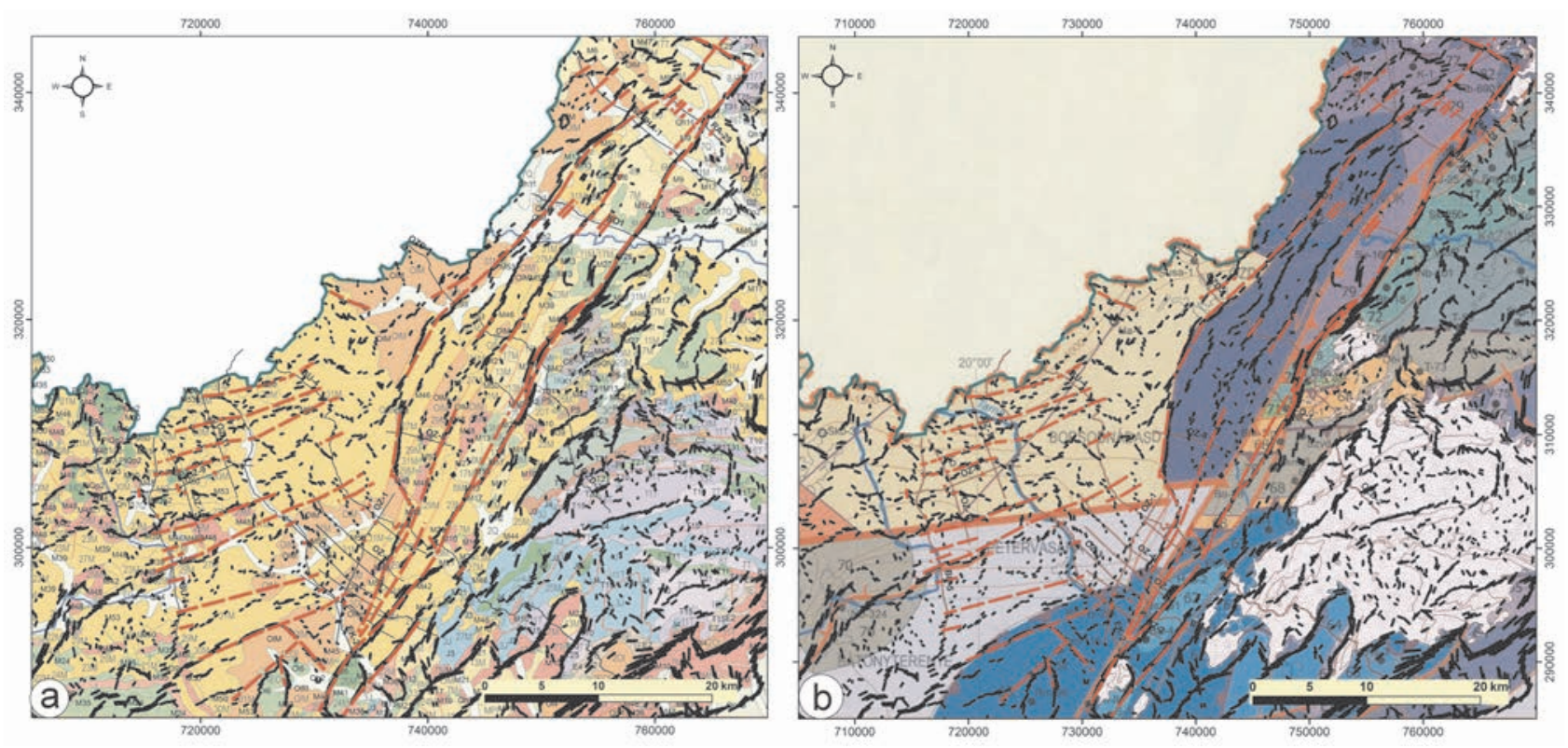

14. ábra. A gravitációs hatóperemek (fekete) és az értelmezett vetők nyomvonalai (piros) a vizsgált terület felszíni földtani térképére (GYALOG et al. 2014) (a) és a prekainozoos aljzattérképre (HAAs et al. 2010) (b) vetítve

Figure 14. Lines of edge detection based on the horizontal gradient of gravity (black) and lines of interpreted faults (red) plotted on the surface geological map (GYALOG et al. 2014) (a) and on the pre-Cenozoic basement map (HAAS et al. 2010) (b) of the studied area

ismert, vagy nem részletezett szerkezeti elemekre, földtani jellegváltásokra.

\section{Diszkusszió — szénhidrogén-földtani vonatkozások}

\section{Szénhidrogén-földtani alapadatok}

A szeizmikus értelmezés alapján a Salgótarjáni-részmedence mélyzónájában elófordulnak az Észak-magyarországi Paleogén-medence bizonyítottan vagy feltételezetten szénhidrogén-generáló anyakőzet összletei, a Budai Márga, a Tardi Agyag és a Kiscelli Agyag Formáció. A meghatározó szintfelületek mélységviszonyai, a környezetben található kőolaj- és földgáz-előfordulások és -indikációk, valamint a tágabb terület (2. ábra) szénhidrogén-földtani adottságai alapján a medencerész szénhidrogének keletkezése és felhalmozódása szempontjából perspektivikus. A továbbkutatás lehetôségének megítéléséhez lényeges a keletkezett szénhidrogének mennyiségének becslése, amelyhez az elkészült térképek mellett az ismert anyakốzetek érettségének és szénhidrogén-generáló potenciáljának adatai szükségesek.

Az Észak-magyarországi Paleogén-medence egészét tekintve a legtöbb oligocén üledékben szárazföldi eredetû́ szerves anyag azonosítható, szénhidrogén-potenciáljuk alacsony. A Tardi Agyagban viszont II és III-as típusú kerogén vegyesen fordul elő, és a formáció felső, laminites része fôképpen kőolaj-generáló, II-es típusú kerogént tartalmaz (MiLota et al. 1995). A Tardi Agyag agyagos aleuritra átszámított szervesanyag-tartalma magas, kloroform- oldható bitumentartalma 0,3-1\%o, átlagosan 0,8\%o. A szerves anyag autochton, szapropél eredetú, sok aromás és naftén szerkezettel, az üledékképződési környezet anoxikus jellegú (BÁLDI 1983). A kinyerhetô bitumen a rezin+ aszfaltén komponensek és a teljes $\mathrm{CH}$-tartalom aránya alapján $(0,2-0,6)$ autochton jellegú, a szénhidrogén / szerves szén aránya 5 és $45 \mathrm{mg} / \mathrm{g}$ közötti. A bitumen prisztán-fitán és prisztán $/ \mathrm{nC}_{17}$ aránya a szerves anyag kevert, szárazföldi és tengeri eredetét mutatja (BRUKNER-WEIN et al. 1983, 1990).

A teljes szerves szén (TOC) tartalom a sötétszürke mikrorétegzett Tardi Agyagban BonCZ et al. (2004) szerint 0,20-4,2 súly\%, átlagosan 1,3\%, a Kiscelli Agyagban 0,24-0,40\%, ritkán 0,5\%. BADICS \& VeTŐ (2012) szerint a Paleogénmedencébő́l származó 92 minta alapján a Tardi Agyag TOCtartalma átlagosan 2,21 súly\% (szélső értékek: 0,41-4,98). A Rock-eval pirolízisból származó, a teljes érési szakaszt bejáró kőzetből még leadható szénhidrogén-mennyiség $\left(\mathrm{S}_{2}\right)$ átlaga $6,47 \mathrm{mg} \mathrm{CH} / \mathrm{g}$ kőzet $(0,34-19,61)$, a kerogén hidrogén gazdagságát mutató hidrogénindex (HI: $\left.100 \times \mathrm{S}_{2} / \mathrm{TOC}\right)$ átlagértéke $252 \mathrm{mg} \mathrm{CH} / \mathrm{g}$ TOC (26-465). Az anyakôzet érettségét jelző vitrinit reflexió $\left(\mathrm{R}_{0}\right)$ értékei $0,43-0,52 \%$ közöttiek, a $\mathrm{T}_{\max }$ értékek (ezen a hőmérsékleten a legintenzívebb a kerogénből történő szénhidrogén-felszabadulás) 404 és $436{ }^{\circ} \mathrm{C}$ között változnak, ami azt jelzi, hogy a vizsgált minták többségének szervesanyag-tartalma éretlen. Az adatokat szúkebb vizsgálati területünkre is reprezentatívnak tekintettük.

Olajipari kutatási jelentések szerint (KósA et al. 2003; Boncz et al. 2012, 2013) az Észak-magyarországi Paleogénmedence déli részén (2. ábra) a potenciális anyakőzetek 2300-2600 méterrel a felszín alatt a kőolajképződés kezdeti, illetve fó fázisában találhatók, a nedvesgáz képződés kezdete 3400-3800 méterre tehető. 
Szúkebb vizsgálati területünkön (1. ábra) az anyakőzetek szerves anyaga érettségének megítélésére az MBFSZ adattárában az egykori Magyar Állami Földtani Intézet (MÁFI) laboratóriumában mért szórványos vitrinit reflexió mérési adatai álltak rendelkezésre. Az adatok az Ózdi-medence DK-i peremi részein mélyült fúrásokból származnak. A Bükkszék Bü-Ny-2 fúrásban a 649,0-677,0 fúrásméter közötti Tardi Agyagból a vitrinit elegyrészek reflexiójának átlaga $\left(\mathrm{R}_{0}\right)$ 0,46\%, a Fedémes Fs-5 fúrásban 338,0-343,0 m-ből 0,35\%, a mérésekhez a minták a Széchenyi Slírból és Pétervásárai Homokkőből származnak. A Recsk R-28 fúrásban 48 m-től 120 m-ig 3 különböző mélységből származó minták $\mathrm{R}_{0}$ értéke $0,45 \%$, a kôzet egri aleurit (JANKOVICH et al. 1984). JÁMBOR et al. (1984) szerint a Bükk hegységtôl nyugatra, a vizsgálati területen, illetve annak szúkebb környezetében mélyült fúrásokból, 240-691 m mélységből származó késô-oligocén-alsó-miocén korú minták jellemző vitrinit reflexió értékei 0,31-0,51\% közöttiek. Az értékek azt jelzik, hogy a vizsgált medenceperemi fúrásokban jelenleg 700 méter felszín alatti mélységben elérhetô kôzetek szerves anyagának érettsége megközelíti vagy akár el is éri a kőolajképződés kezdetéhez kapcsolható értéket.

A Salgótarjáni-és az Ózdi-medencerész területén mélyült fúrásokból Rock-eval pirolízis vizsgálatok nem állnak rendelkezésre. A vizsgált terület anyakőzeteinek szénhidrogéngeneráló potenciáljára - az anyakőzetek kifejlődésének, illetve szervesanyag-tartalmának egy bizonyos tartományon belüli hasonlóságát feltételezve — távolabbi fúrásokból rendelkezésre álló adatok alapján következtettünk. Publikált adatok a Budapesttől 30 km-re Ny-ra mélyített Alcsútdoboz Ad3 fúrásból, a Zagyva-árok középsố szakaszában mélyült Nagykökényes Nks-I, a Bükkalján, a Vatta-Maklári-árok északi peremén mélyült Cserépváralja Csv-1, a Budapest közelében mélyült Veresegyház Ve-1 és Kiscell $\mathrm{K}-1$ fúrásokból álltak rendelkezésre (BRUCKNER-WEIN et al. 1983, 1990, Vető 1997, BADICS \& VetŐ 2012, BeChtel et al. 2012).

BADICS \& VETŐ (2012) szerint a Csv-1, V-1, Ad-3, Nks-1 fúrások TOC és a Rock-eval pirolízis mérésból adódó szénhidrogén-potenciál $\left(S_{2}\right)$ adatai alapján a Tardi Agyag felsô, laminites részére az eredeti, éretlen kőzet hidrogénindexe $\left(\mathrm{HI}_{\mathrm{o}}\right)$ jó közelítéssel átlagosan $433 \mathrm{mg} \mathrm{CH}$ / g TOC, amely a generált szénhidrogén-mennyiség becsléséhez jelent fontos adatot.

A perm, a triász és a jura üledékrétegekben feltételezhetô szénhidrogén-generáló anyakőzetek jelenléte, erre azonban közvetlen bizonyíték nincsen. A szénhidrogének megjelenése szempontjából a metamorf kristályos aljzat képződményei nem perspektivikusak, mivel egykori szénhidrogén-tartalmuk biztosan átalakult, amelynek nyomai a grafitos palákban találhatók. Azonban mint repedezett, tört tárolókő́zetek, van jelentőségük. (KőRÖssY 2004).

A vizsgált területen a paleogén ciklus üledékeire egykor rátelepülő, majd részben leereodálódott kôszéntelepes összlet (Salgótarjáni Barnakőszén Formáció) és miocén fedőüledékei szénhidrogén-földtani szempontból az alattuk települő kőzetek megfelelő érettségét biztosíthatták (PÜSPÖKI et al. 2017). Az anyakôzetek érettségének szempontjából loká- lis jelentôsége van az üledékes rétegsorokat áttörô oligocén Recski Andezit és a miocén badeni-szarmata Mátrai Vulkanit Formációcsoport teléreinek, amelyek helyi felfútéssel az anyakőzetek szerves anyagának érettségét is növelhették (ARATó 2018).

\section{Süllyedéstörténeti adatok}

A vizsgált terület szénhidrogén anyakôzetei érettségének megítéléséhez fontos süllyedéstörténeti modellezést végzett HoRváth et al. (1990) az Észak-magyarországi Paleogén medence $22 \mathrm{db}$ mesterkútjában fúrási rétegsorok, a vitrinit reflexió, a becsült paleohómérséklet és a vízmélység adatai alapján. A vizsgált területre a modellezett kutakból a Salgótarjáni-részmedence peremére aBükkszék BüNy-2, Fedémes, Fs-4, a Susa-1 és a Recsk, R-89, -103. jelú fúrások esnek, a Nagybátony-I és a Sóshartyán-3 fúrás pedig a vizsgált terület nyugati peremén található (2. ábra). Az adatok alapján meghatározták a paleogén és neogén medencekitöltés érettségének a mélység függvényében való előrehaladását, a kőolaj- és a gázgeneráló zóna hozzávetőleges vertikális kiterjedését. A modellezés eredményét minden fúrásra egy-egy süllyedéstörténeti diagram összegzi. Sajnos a diagramok az oligocén és alsó-miocén emeletek földtörténeti korának változásai miatt nem rekonstruálhatóak kielégítő mértékben, mégis fontos támpontot nyújtanak a kőolajgeneráló zóna mélységének megítéléséhez.

Az említett fúrások süllyedéstörténeti diagramjai alapján a medence a késô-eocéntôl a szarmatáig változó mértékú, de általánosan süllyedő trendet mutat, a medenceperemi fúrásokban elért képződmények ekkor érték el legmélyebb felszín alatti helyzetüket, ellentétben a Paleogén-medence déli részén mélyült fúrások modelleredményeivel, ahol a süllyedés esetleges kisebb megszakításokkal, de a felsôpannóniai képződmények lerakódásáig folyamatos volt. Az említett fúrásokban a szerves anyag érettsége nem éri el a kőolaj generálódáshoz szükséges mértéket $(0,6 \%$ vitrinit reflexióérték), de a reflexióértékek mélység függvényében való változásának mértékéből következtetve megbecsülhetô a kőolajgeneráló zóna („olajablak”) elvi mai tetômélysége. A JANKOVICS et al. (1984), JÁMBOR et al. (1984) fent említett vitrinit reflexió adatai, HoRvÁTH et al (1990) süllyedéstörténeti grafikonjai alapján a Salgótarjáni-részmedencében a kezdeti olajképződés határát -1600 és -2000 méter felszín alatti mélységre becsüljük, szemben az Észak-magyarországi Paleogén-medence déli részére jellemző, fent említett 2300-2600 méter mélységgel. A Salgótarjáni-részmedence területén döntően az alsó-miocén Pétervásárai és Zagyvapálfalvai Formációk vannak felszínen, tehát a medenceinverzióból következó erózió a mélyebb medencerészen is jelentős volt. A medencerész érett anyakôzetei lehetnek forrásai a területet dél és kelet felól ívesen határoló nagybátonyi, recski, bükkszéki, fedémesi szénhidrogén-elófordulásoknak és- indikációknak (15. ábra a).

Az elképzelést két közelmúltban megjelent publikáció eredményei is megerósítik. BEKE et al. (2019) a Bükk hegység nyugati és déli előterének terepi feltárásaiban vizsgálta felsô- 

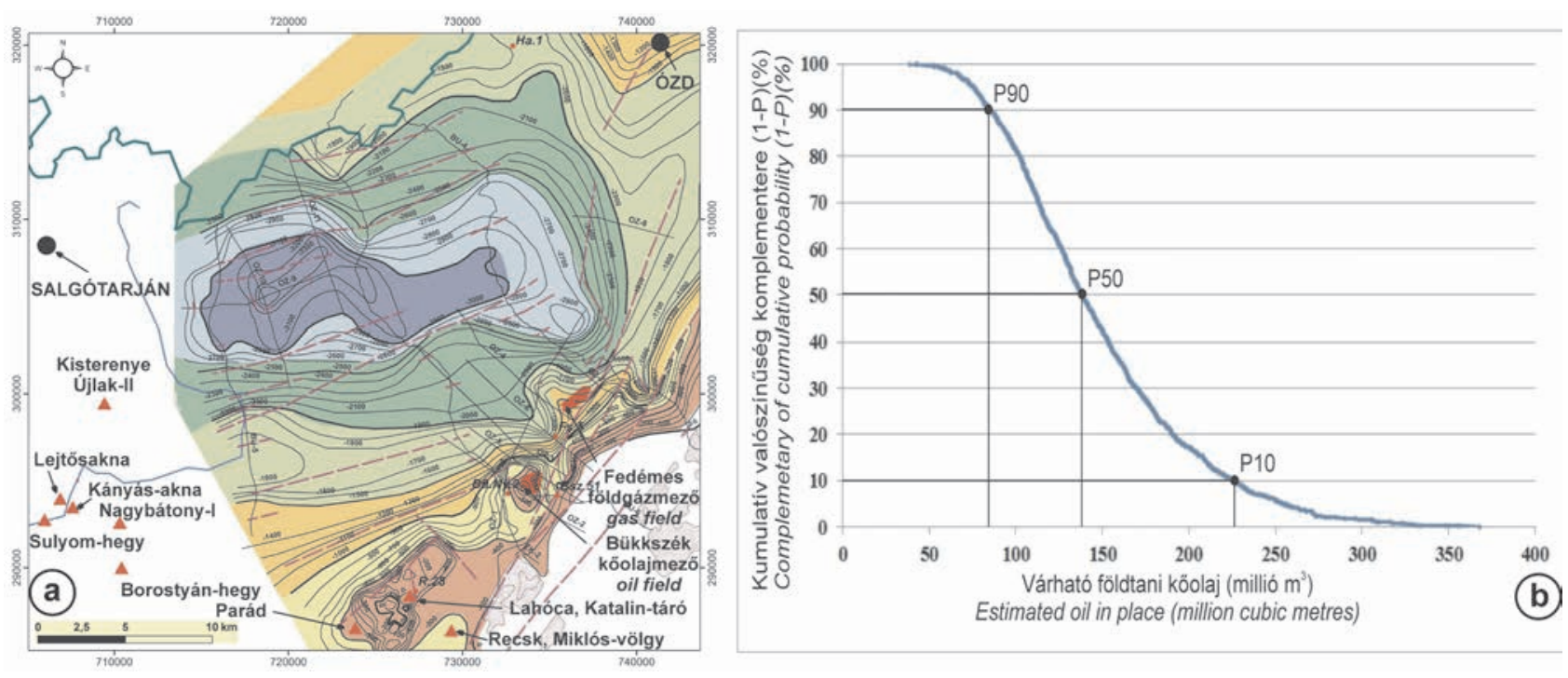

15. ábra. Ismert kőolaj előfordulások, olajnyomok (piros háromszög) a vizsgált terület délnyugati részén, háttérben a prekainozoos aljzat mélységviszonyai (a); és a Tardi Agyag anyakőzet által generált reménybeli földtani kőolajvagyon valószínủségeloszlása (b)

Figure 15. Known oil occurences and shows (red triangle) in the southwestern part of the area with the pre-Cenozoic basement depth in the background (a); and the probability distribution of generated oil in-place originated from the Tard Clay source rock (b)

oligocén-alsó-miocén kôzetkibúvások deformációs szalagjait. Az egyes deformációs szalagtípusok sorba rendezhetók, hozzájuk különböző betemetôdési mélységintervallumok rendelhetők, ez alapján minden deformációval érintett sztratigráfiai szintre süllyedéstörténeti görbe készült. A NógrádSalgótarjáni medenceterületre vonatkozó görbe szerint az oligocén képződmények tetejének betemetődése a középsőmiocén végére már meghaladta az 1600 métert, majd később, a terület a mintegy 6 millió éve kezdôdött inverziója során kb. 400 métert emelkedett. A Darnó-zóna (Ózdi-részmedence) területén a süllyedés mérsékeltebb volt, az emelkedés sokkal hangsúlyozottabb, mintegy 600 méter.

ARATó et al. (2019) a vizsgálati területünk (1. ábra) déli peremén húzódó Mátra hegységi miocén vulkanizmus hőhatását vizsgálta a fekvő felsô-oligocén-alsó-miocén üledékösszletre vonatkozóan a recski oligocén szubvulkáni intrúzió környezetében apatit és cirkon U-Th/He termokronometriai módszerrel. Hő- és süllyedéstörténeti modelljük szerint a recski magmás komplexum teteje (a fedő üledékösszlet alja) a mátrai miocén vulkanizmus során 1000-1500 méter mélységbe süllyedt, majd a vulkanizmust intenzív erózió és a recski komplexumnak a késô-miocénre (kb. 7 Ma) a felszínig tartó emelkedése követte.

\section{A vizsgált terület potenciális szénhidrogén- vagyona}

A bemutatott geofizikai értelmezés, az elkészült térképek és a rendelkezésre álló szervesanyag-érettség és szénhidrogénpotenciál adatai alapján a keletkezett szénhidrogén-mennyiségre egy nagyvonalú prognosztikus vagyonbecslés végezhetô. A becslés a Salgótarjáni-részmedencére készült el. Az Ék2 szeizmikus szelvényen (7. ábra) jelölt 1 . és 2 . horizont közötti összletben települ a kialakított szénhidrogén-földtani kép alapján egy közel 50-100 méter vastag jó szénhidrogén (fóként kőolaj-) generáló Tardi Agyag összlet, ezen felül a Budai Márga és a Kiscelli Agyag magas szervesanyag-tartalmú része is növelhetik a produktív anyakőzet vastagságát.

A becslés SCHMOKER (1994) alábbi, széles körben használt összefüggését felhasználva, azt kis mértékben módosítva készült:

$$
\mathrm{CH}_{\text {gen }}=\mathrm{T} \times \mathrm{V} \times \mathrm{TOC} \times \mathrm{S}_{\mathrm{k}} \times \mathrm{R} \times \mathrm{O}_{\text {gen }} \times 1 / \mathrm{S}_{\text {oil }} \text {, ahol }
$$

$-\mathrm{CH}_{\text {gen }}$ : a vizsgált térrészben generálódott kőolaj mennyisége (millió $\left.\mathrm{m}^{3}\right)$,

— T: az anyakôzet összlet területe (millió $\mathrm{m}^{2}$ ),

— V: az anyakőzet összlet vastagsága $(\mathrm{m})$,

— TOC: az anyakôzet összlet átlagos szerves széntartalma (súly\%/100),

- $\mathrm{S}_{\mathrm{k}}$ : az anyakôzet összlet átlagos súrúsége $\left(\right.$ tonna $\left./ \mathrm{m}^{3}\right)$,

- R: nettó egységnyi generálódott szénhidrogén, $\mathrm{HI}_{\mathrm{o}}-\mathrm{HI}_{\mathrm{p}}$, az éretlen és az érett anyakőzet mért, illetve becsült hidrogénindexe alapján ( $\mathrm{kg} \mathrm{CH} /$ tonna TOC),

$-\mathrm{O}_{\text {gen }}$ : a generálódott szénhidrogénekből a kőolaj aránya $(\% / 100)$,

- $\mathrm{S}_{\text {oil }}$ : a kốolaj átlagos súrúsége $\left(\right.$ tonna $\left./ \mathrm{m}^{3}\right)$

A becsléshez felhasznált paraméterek:

— az anyakőzetek elterjedési területe: $125-200 \mathrm{~km}^{2}$,

— jó szénhidrogén-generáló anyakôzetek (Tardi Agyag) vastagsága: $50-100 \mathrm{~m}$.,

— a kôzet súrúsége: $2,3-2,5$ tonna $/ \mathrm{m}^{3}$,

— az eredeti teljes szerves széntartalom (TOC): 1,5-3 súly\%,

— az eredeti (éretlen kőzet) hidrogénindexe $300-500$ kg

$\mathrm{CH} /$ tonna TOC,

— a jelenlegi (részben érett kőzet) hidrogénindexe 150-200

$\mathrm{kg} \mathrm{CH} /$ tonna TOC,

- a generált szénhidrogén ( $\mathrm{HI}_{\text {orig }}-\mathrm{HI}_{\text {jelenlegi }}: 150-300 \mathrm{~kg}$ $\mathrm{CH} /$ tonna TOC,

— a nettó generált kőolajarány: 80-90\%, a kőolaj sưrúség: $0,85 \mathrm{~kg} / \mathrm{m}^{3}$. 
Az egyes paraméterek értéktartományát valószínúségi változóként kezelve, az Excel program „véletlen.között” függvényének használatával ún. Monte Carlo-szimulációt végeztünk. A fenti „ $\mathrm{CH}_{\text {gen }}$ ” függvény értékét 1000 alkalommal kiszámoltatva, majd az eredményeket grafikonon ábrázolva az alábbi görbét kapjuk (15. ábra b).

A görbe P90 (óvatos becslés, legalább $90 \%$ a valószínúsége, hogy a generált mennyiség ennyi vagy több) értékéhez tartozó mennyiség 85 millió $\mathrm{m}^{3}$, a P50 (legjobb becslés) 138 millió $\mathrm{m}^{3}$, a P10 (optimista becslés) 225 millió $\mathrm{m}^{3}$. Ez az érték tartalmazza a helyben maradt és a környezetébe elmigrált mennyiséget is.

\section{Lehetséges tárolókôzetek és migrációs jelenségek}

A vizsgált területen a paleogén képződmények közül a környező medenceterületen megismertek alapján az aljzatra települő eocén konglomerátum, homokkő (Kosdi Formáció), a felsố-eocén mészkő (Szépvölgyi Mészkő), márga, felsô-eocén-alsó-oligocén repedezett agyagmárga (Budai Márga), az oligocén homokkő, tufa- és mészkő betelepülések (Tardi, Kiscelli), továbbá lokálisan a felsőoligocén és alsó-miocén homokövek (Egri Formáció, Pétervásárai Homokkő Formáció) jönnek számításba tárolókôzetként (KóRÖSSY 2004, BABINSZKI et al. 2018, 4. ábra). A csapdák zárását a tárolók fölé települt agyagok, agyagmárgák, lokálisan a miocén vulkáni tufák és tufitok impermeábilis rétegei adják. Az aljzati maximumokhoz köthető csapdák mellett az oligocén képződményeken belül kialakult litológiai-szerkezeti csapdákban is felhalmozódhatott jelentősebb mennyiségú szénhidrogén. Az anyakőzet-szintek közé ékelődő, megfelelő porozitással és permeabilitással rendelkezô szállítórétegek megléte kedvezôen hathat az elsődleges migrációra.

Az Észak-magyarországi Paleogén-medence szénhidrogén-földtani modellje szerint a medencében elsôsorban rövid távolságú horizontális és vertikális migrációval kell számolni, tehát a szénhidrogének a csapda környezetében lévő mélyzónákból származhatnak. Azok a tároló objektumok perspektivikusak, melyek az anyakőzetekkel közvetlen kapcsolatban állnak, vagy hozzájuk igen közel helyezkednek el (BoncZ et al. 2012, 2013).

A Salgótarjáni-részmedence földtani felépítése alapján az itt keletkezett kőolaj és földgáz jelentős része az anyakőzet összletekben maradhatott (nem hagyományos szénhidrogén-előfordulás), vagy nem túl jelentős távolságra, a Kiscelli Agyagba települt törmelékes-tufás rétegekbe, illetve szomszédos kôzetösszletekbe migrálhatott, esetenként a felszínig is eljutva (Bükkszék, Recsk, Parád, Lahóca, Fedémes). Felhalmozódási helyként a repedezett aljzati tárolók, és az azt fedő törmelékes összlet is számításba vehetô, fúrható egyedi szerkezetek (proszpektek) kimutatásához azonban további szeizmikus mérések és értelmezések szükségesek.

\section{Következtetések}

A munka keretében a szeizmikus és gravitációs, illetve fúrási adatok együttes értelmezése alapján a Salgótarjáni- és Ózdi-részmedencékre elóállított részletes prekainozoos medencealjzat-térképen a medencerészek geometriája a korábbinál pontosabban követhetố. Az elkészült aljzattérkép a korábbi, országos léptékú, medencealjzatot ábrázoló térképeknél részletesebb felbontású, a szeizmikus és gravitációs új értelmezéséket magába foglaló térképváltozat. Különösen érzékelhetô a medencealjzat lefutásának változása a recski, bükkszéki és a fedémesi boltozat térségében, a mélymedence felé való átmenet domborzatában, és a Salgótarjáni-részmedence rajzolatában.

A gravitációs medencemodell a medencealjzat eltérő kőzettani felépítését mutatja a terület ÉK-i és Ny-i részén, amely összhangban van a prekainozoos aljzat korábbi (HAAs et al. 2010) földtani térképével. A gravitációs hatóperemek térképe alapján a szerkezeti vonalak és a földtani képződményhatárok elhelyezkedése pontosítható.

A szeizmikus vonalak mentén lehetőség volt öt markáns reflexiós szint követésére, amelyek kapcsolatba hozhatók az eocén Szépvölgyi Mészkő / Budai Márga, az oligocén Tardi Agyag, Kiscelli Agyag, a felsô-oligocén-alsó-miocén Szécsényi Slír / Pétervásárai Homokkő és a fedô kőszéntelepes miocén összlet elterjedési és formációhatáraival.

A mélységbe konvertált szeizmikus szelvények értelmezése szerint mélységét és kitöltését tekintve a vizsgált terület két részterületre osztható. A Ny-i része (Salgótarjáni-részmedence) -3000 méter tszf.-nél is mélyebbre süllyed, és KÉK-NyDNy-i tengelyú mélyzónát mutat, melynek kitöltésében a késô-eocén-kora-oligocén üledékes összletek is megjelennek. A medence ÉK-i része (Ózdi-részmedence) -2000 méter tszf.-nél sekélyebb, üledékkitöltésében a Kiscelli Agyagnál idősebb oligocén képződmények hiányoznak, a medenceszerkezet ÉK-DNy-i tengelyú zónát mutat.

Szénhidrogén-kutatás szempontjából a potenciális anyakôzetek elterjedése a korábbinál alaposabban értékelhetô. A korábban véltnél mélyebb és kiterjedtebb mélymedence jelenléte kedvező a szénhidrogén anyakőzetek elterjedése, érettsége szempontjából. A Salgótarjáni-részmedencében térképezhetôek azok a horizontok, amelyeken belül az anyakőzet formációk elhelyezkednek.

A kőolaj és földgáz ismert előfordulásai jelzik, hogy a Salgótarjáni-részmedencében a szénhidrogének anyakôzetei (elsősorban a Tardi Agyag laminites márgarétegei és a Kiscelli Agyag alsó része) érettek, a kőolaj- és földgáz-előfordulások (a Tardi Agyag és a Kiscelli Agyag homokkő és tufás rétegei, lencséi) pedig az anyakőzetekben vagy azok szúk környezetében vannak, és a szénhidrogének migrációja korlátozott. A vizsgált területról rendelkezésre álló információk alapján a kőolaj-indikációk, -előfordulások jelentős részben az anyakôzetekben, azok homok- vagy tufalencséiben tározódnak, a kőzetrepedések sok helyen olajfilmmel bevontak.

A medence peremi mélyfúrásokból származó vitrinit reflexió adatai azt mutatják, hogy a ma felszínközelben lévő 
mintázott kőzetrészek a kőolaj-generálódás kezdeti fázisának közelébe jutottak, tehát a vizsgált térrész korábban a jelenleginél mélyebben volt eltemetve.

A generált kôolaj mennyisége prognosztikus becslésünk szerint meghaladhatja a 100 millió $\mathrm{m}^{3}$-t.

A szénhidrogénekre való részletes továbbkutatást indokolja, hogy a területen a hazai lehetôségekhez képest kedvezőbb mélységi, hőmérséklet- és nyomásviszonyok mellett érett és szerves anyagban gazdag anyakőzet ismert. Úgy gondoljuk, hogy a bükkszéki és fedémesi szénhidrogénelőfordulások hazai viszonylatban korai sikeres felfedezése és gyors letermelése nem járt együtt a ma már elérhető szín- vonalú megkutatással, ezért a terület továbbkutatása perspektivikus.

\section{Köszönetnyilvánítás}

Köszönjük a Magyar Bányászati és Földtani Szolgálat vezetőinek és kutatóinak, hogy támogatták és segítették a tanulmány elkészítését. Szintén köszönjük részletes észrevételeiket és javításaikat lektorainknak, LEMBERKOvics Viktornak és PETRIK Attilának, illetve FoDOR László szakszerkesztőnek és SzTANó Orsolya főszerkesztőnek.

\section{References — Irodalom}

Albu I., Braun L. \& Szalay I. 1985: Az Aggtelek-Rudabányai-hegység geofizikai előkutatása. — A Magyar Állami Eötvös Loránd Geofizikai Intézet 1984. évi jelentése, Budapest, 29-33.

Arató, R., Dunkl, I., TAKÁcs, Á., Szebényi, G., Gerde, A. \& Eynatten, H. 2018: Thermal evolution in the exhumed basement of a stratovolcano: case study of the Miocene Matra Volcano, Pannonian Basin. — Journal of the Geological Society, London 175, 820 835. https://doi.org/10.1144/jgs2017-117

BABINSZKI E., KeRCSMÁr Zs. \& KovÁCs Zs. 2018: Magyarország szénhidrogén-kutatási területei — a Paleogén-medence. — In: KovÁCS Zs. (szerk.): Szénhidrogének Magyarországon. — A Magyar Energetikai és Közmú-szabályozási Hivatal kiadványa, Budapest, 179_ 195. http://www.mekh.hu/download/3/20/60000/ szenhidrogenek_magyarorszagon.pdf

BADICS, B. \& VeTő, I. 2012: Source rocks and petroleum systems in the Hungarian part of the Pannonian Basin: The potential for shale gas and shale oil plays. — Marine and Petroleum Geology 31, 53-69. https://doi.org/10.1016/j.marpetgeo.2011.08.015

BÁLDI T. 1980: A korai Paratethys története. — Földtani Közlöny 110, 456-472.

BÁLDI T. 1983: Magyarországi oligocén és alsó miocén formációk. — Akadémiai Kiadó, Budapest, 293 p.

BÁLDI, T. \& BÁLDI-BEKE, M. 1985: The evolution of the Hungarian Paleogene basins. —Acta Geologica Hungarica 28, 5-28.

BÁLDI T. \& SzTANó O. 2000: Gravitációs tömegmozgások a Darnó zóna tengeri oligo-miocén üledékeiben: a Dubicsány-31 fúrás értékelése. - Földtani Közlöny 130, 673-694.

BALOGH K. 1964: A Bükkhegység földtani képződményei. — A Magyar Állami Földtani Intézet Évkönyve 48, 719 p.

Bechtel, A., Hámor-Vidó, M., Gratzer, R., Sachsenhofer, R. F. \& PÜttmann, W. 2012: Facies evolution and stratigraphic correlation in the early Oligocene Tard Clay of Hungary as revealed by maceral, biomarker and stable isotope composition. - Marine and Petroleum Geology 35, 55-74. https://doi.org/10.1016/j.marpetgeo.2012.02.017

Beke, B., Fodor, L., Millar, L. \& Petrik, A. 2019: Deformation band formation as a function of progressive burial: Depth calibration and mechanism change in the Pannonian Basin (Hungary). — Marine and Petroleum Geology 105, 1-16. https://doi.org/10.1016/ j.marpetgeo.2019.04.006

BeUdAnt, F. S. 1822: Voyage minéralogique et géologique en Hongrie, pendant l'année 1818. — Tome III., Paris, 261 p.

Blakely, R. J. \& Simpson, R. W. 1986: Approximating edges of source bodies from magnetic or gravity anomalies. - Geophysics 51, 1494-1498. https://doi.org/10.1190/1.1442197

Braun L., Petrovics I. \& Szalay, I. 1989: A Szuha-völgye és a darnó-öv reflexiós szerkezetkutatása. — Az Eötvös Loránd Geofizikai Intézet Évi jelentése az 1987. évról, Budapest, 39-44.

Bruknerné Wein A., Vetô I. \& Dudich E. 1983: Az anoxikus Tardi Agyag (oligocén) üledékképződésének geokémiai vizsgálata. — A Magyar Állami Földtani Intézet Évi jelentése az 1983. évról, Budapest, 271-301.

BRUKNER-Wein, A., HetÉnYI, M. \& VeTő, I. 1990: Organic geochemistry of an anoxic cycle: a case history from the Oligocene section, Hungary. — Organic Geochemistry 15, 123-130. https://doi.org/10.1016/0146-6380(90)90077-d

Boncz L., Balázs E., Bartha A., Kósa L., Milánkovich A., Nagy Gy.-NÉ, Séllei Cs., Vadász Gy.-NÉ, Szentgyörgyi K.-NÉ, Tóth J. \& TóTH L.-NÉ 2004: Zárójelentés a 103. Gödöllő kutatási területen végzett szénhidrogén-kutatási tevékenységrôl. — Kézirat, MOL Rt., Magyar Földtani, Geofizikai és Bányászati Adattár, Budapest, T.21172.

Boncz L., Sőreg V., Balázs E.-NÉ, Eszes I.-NÉ, Krusoczki T. Gy., Lux M., Pusztai J., Szabóné László A., SzÁszfai J. \& Tomcsányi T. 2012: Zárójelentés a 136. Bátonyterenye területen végzett szénhidrogén-kutatási tevékenységról. — Kézirat, MOL Rt. Magyar Földtani, Geofizikai és Bányászati Adattár, Budapest, T.22518., p. 54.

Boncz L., Sôreg V., Balázs E.-né, Lux M., Klemenik R., Krusoczki T., Pusztai J., Szászfai J., Tomcsányi T., Gyergyói L., Mészáros V. Cs., Zsuppán Gy., Milánkovich A., Kormos L., Szalainé Bánlaki E., SzabónÉ Veres É., Vida E., Bozsó M.-NÉ \& TöröK J.-NÉ 2013: Zárójelentés a 138. Monor területen végzett szénhidrogén-kutatási tevékenységről. — Kézirat, MOL Nyrt., Magyar Földtani, Geofizikai és Bányászati Adattár, Budapest, T.22781. 
CORDELL, L. 1985: A stripping filter for potential field data. - 55th Annual International Meeting, SEG, Expanded abstract, 217-218.

CORDELL, L. \& GRAUCH, V. J. S. 1987: Limitations of determining density or magnetic boundaries from horizontal gradient of gravity or pseudogravity. — Geophysics 52/1, 118-121. https://doi.org/10.1190/1.1442236

CsÁszÁr G. (szerk.) 1997: Magyarország litosztratigráfiai alapegységei. — A Magyar Állami Földtani Intézet kiadványa, Budapest, 105 p.

FODOR L. 2010: Mezozoos-kainozoos feszültségmezők és törésrendszerek a Pannon-medence ÉNy-i részén — módszertan és szerkezeti elemzés. - Kézirat, Akadémiai doktori értekezés, 167 p.

Fodor, L., Csontos, L., BAdA, G., Győrfi, I. \& Benkovics, L. 1999: Tertiary tectonic evolution of the Pannonian basin system and neighbouring orogens: a new synthsis of palaeostress data. — In: Durand, B., Jolivet, L., Horváth, F. \& SÉranne, M. (eds): The Mediterranean basins: Tertiary extension within the Alpine orogen. — Geological Society, London, Special Publications 156, 295334. https://doi.org/10.1144/gsl.sp.1999.156.01.15

FODOR, L. \& KÁZMÉr, M. 1989: Clastic and carbonate sedimentation in an Eocene strike-slip basin at Budapest. — In: CsÁsZÁR, G. (ed.): Tenth IAS Regional Meeting, Excursion Guidebook, Budapest, 227-259.

Fodor, L., MAGYARI, Á., KÁzMÉr, M. \& Fogarasi, A. 1992: Gravity-flow dominated sedimentation on the Buda paleoslope (Hungary): record of late Eocene continental escape of the Bakony unit. — Geologische Rundschau 81, 695-716. https://doi.org/10.1007/ bf01791386

Fodor, L., Radócz, Gy., Sztanó, O., Koroknai, B., Csontos, L. \& Harangi, Sz. 2005: Post-Conference Excursion: Tectonics, Sedimentation and Magmatism along the Darnó Zone. - GeoLines 19, 142-162.

Grill J., KovÁcs S., Less Gy., RéTi Zs., Róth L. \& SzEnTPÉTERY I. 1984: Az Aggtelek-Rudabányai-hegység földtani felépítése és fejlődéstörténete. - Földtani Kutatás 27/4, 49-56.

Gyalog L. (szerk.), Pelikán P., Selmeczi I., Gulácsi I. \& Radócz Gy. 2014: Magyarország földtani térképe 1:500 000 (Geological map of Hungary 1:500 000). — Magyar Földtani és Geofizikai Intézet, Budapest.

HaAs J., Budai T., Csontos L., FodOR L. \& KonRÁd Gy. 2010: Magyarország pre-kainozoos földtani térképe 1: 500000 (Pre-Cenozoic geological map of Hungary, 1:500,000). — Magyar Földtani és Geofizikai Intézet, Budapest.

HAAS J. \& BUDAI T. (szerk.) 2014: Magyarország prekainozoos medencealjzatánakföldtana. Magyarázó „,Magyarország pre-kainozoos földtani térképéhez" (1:500 000). (Geology of the pre-Cenozoic basement of Hungary, Explanatory book of the pre-Cenozoic geological map of Hungary 1:500 000.) — Magyar Földtani és Geofizikai Intézet, Budapest, 71 p.

Hajdú J., Balázs E., Bujdosó I., Czeller I., Eszes I-né, NaGy Gy-NÉ, PÁPa A., Soós S., Szentgyörgyi K-NÉ \& VadÁsz Gy-NÉ 1997: Zárójelentés a 26. Ózdi medence területen végzett szénhidrogén-kutatási tevékenységről. — Kézirat, MOL Rt., Magyar Földtani, Geofizikai és Bányászati Adattár, Budapest, T.20133., 25 p.

HÁmor G. 1985: A Nógrád-Cserháti kutatási terület földtani viszonyai. — Geologica Hungarica series Geologica 22, 316 p.

HERNYÁK G. 1977: A Rudabányai-hegység szerkezeti elemzése az elmúlt 20 év kutatásai alapján. — Földtani Közlöny 107, 368-374.

Horváth F., LENkey L., DövéNYI P. \& NAGYMarosi A. 1990: Az Északmagyarországi paleogén medence süllyedés- és hőtörténeti modellezése. - Kézirat, Kutatási jelentés, Eötvös Loránd Tudományegyetem Geofizikai Tanszék, Budapest, 51 p., Magyar Földtani, Geofizikai és Bányászati Adattár, T.22768

Jámbor Á., Halmai J., Jankovich I., Kárpátiné Radó D., Ravasz Cs., TANÁcs J., Thamóné Bozsó E., Brucknerné Wein A., Laczó I., SzỨCs I. \& VETő I. 1984: Észak-Magyarország szénhidrogén prognózisa I-II. — Kézirat, Előzetes jelentés, Magyar Állami Földtani Intézet, Budapest, 86 p., Magyar Földtani, Geofizikai és Bányászati Adattár, T. 22617

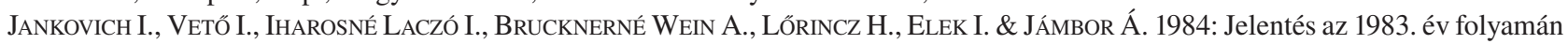
végzett észak-magyarországi szénhidrogén prognózis anyagvizsgálati munkálatairól I-III. — Kézirat, Magyar Állami Földtani Intézet, Budapest, 735 p., Magyar Földtani, Geofizikai és Bányászati Adattár, T. 22602

JASKÓ S. 1946: A Darnó-vonal. — Beszámoló a MÁFI Vitaüléseiról 7, Budapest, 63-77.

JASKÓ S. 1989: A Darnó-vonal környékének felsô-miocén tektonikája. — A Magyar Állami Földtani Intézet Évi Jelentése az 1987. évról, 395-409.

KÁZMÉr M. 1984: A Bakony horizontális elmozdulása a paleogénben. —Általános Földtani Szemle 20, 55-102.

KÁzmér, M., Dunkl, I., Frisch, W., Kuhlemann, J. \& OzsváRT, P. 2003: The Paleogene forearc basin of the Eastern Alps and Western Carpathians, subduction, erosion and basin evolution. — Journal of the Geological Society, London 160, 413-428. https://doi.org/ 10.1144/0016-764902-041

Kilényi, É., Kröll, A., Obernauer, D., Šefara, J., Steinhauser, P., Szabó, Z. \& Wasserly, G. 1991: Pre-Tertiary basement contour map of the Carpatian basin beneath Austria, Czechoslovakia and Hungary. — Geopysical Transactions 36/1-2, 15-36.

Kiss J. 2006: Magyarország gravitációs lineamenstérképe — elsô eredmények. — Magyar Geofizika 47/2, 1001-1010.

KISS J. 2009: Regionális gravitációs anomáliák, izosztatikus hatások Magyarországon. — Magyar Geofizika 50/4, $153-171$.

Kiss J. 2010: Mély medencék izosztatikus hatása. — Magyar Geofizika 51/3, 1-13.

Kiss J. 2014: Magyarország Bouguer-anomália térképének frekvenciatartománybeli vizsgálata és értelmezése. — Magyar Geofizika 55/4, 163-178.

KitAiBel P. 1829: Hydrographia Hungariae. — Edit J. Schuster I-II. Pest, 162-204.

Kósa L., Balázs E.-Né, Bartha A., Boncz L., Kovács A., Nagy Gy.-Né, SÉllei Cs., Tóth L.-Né, Tóthné Medvei Zs. \& TöRÖK V.-NÉ 2003: Zárójelentés a 111. Salgótarján kutatási területen végzett szénhidrogén-kutatási tevékenységről. — Kézirat, MOL Rt., Magyar Földtani, Geofizikai és Bányászati Adattár, Budapest, T.21124, 26 p.

Kovács Zs., Angyal J., CSERkÉsz-Nagy Á., Gulyás Á., Guthy T., Kiss J., LukÁcsy J., Kovács A. Cs., Prakfalvi P., PüspöKi Z., Szalay I., SzentPÉTERY I., Vértesy L., VAd A., Vlasics P. \& Zilahi-SEbess L. 2015: A Salgótarján-Fedémes-Ózd paleogén-medencerész medencealjzat-térképének elkészítése szeizmikus mélységszelvények és gravitációs mérési adatok felhasználásával. - Kézirat, Zárójelentés, M2-8/2014 MBFH-MFGI együttmúködés, MÁFBGA adattára, Budapest, 99 p. 
KovÁCSVÖLGYI S. \& ScHÖNVISZKY L. 1991: Jelentés a Bükk-hegység és előterei komplex földtani előkutatási program keretében végzett gravitációs mérésekről. — Kézirat, MÁELGI, Magyar Földtani, Geofizikai és Bányászati Adattár, Budapest, AD. 1133.

KŐRÖSSY L. 2004: Az észak-magyarországi paleogén medence kőolaj- és földgázkutatásának földtani eredményei. —Általános Földtani Szemle 28, Budapest, 9-121.

Less Gy., Grill J., Róth L., Szentpétery I. \& GyuricZa Gy. 1988: Az Aggtelek-Rudabányai-hegység földtani térképe 1:25 000. — Magyar Állami Földtani Intézet, Budapest.

Less, Gy., Mello, J. (eds), ElečKo, M., Kovács, S., Pelikán, P., Pentelényi, L., Peregi, Zs., Pristaš, J., Radócz, Gy., Szentpétery, I., VAss, D., VozÁr, J. \& VozÁrová, A. 2004: Geological Map of the Gemer-Bükk area 1:100 000. — Geological Institute of Hungary, Budapest and SGÚDS, Bratislava.

Less Gy., Kovács S., Szentpétery I. (eds), Grill J., Róth L., Gyuricza Gy., SÁsdi L., Piros O., Réti Zs., Elsholtz L., Árkai P., Nagy E., Borka Zs., Harnos J. \& ZelenKa T. 2006: Az Aggtelek-Rudabányai-hegység földtana. — Magyarázó az Aggtelek-Rudabányaihegység 1988-ban megjelent 1:25 000 méretarányú fedetlen földtani térképéhez. Magyar Állami Földtani Intézet, Budapest, 92 p.

Majzon L. 1940: A bükkszéki mélyfúrások. - A Magyar Királyi Földtani Intézet Évkönyve 34/2, 275-386.

MATYASOVSZKY J. 1885: A mátrahegységbeli (recski) petroleumelőfordulás. — Földtani Közlöny 15, Budapest, 173 p.

MADARASI A. 1990: Észak-Magyarország regionális földtani kutatása: Tellurikus és magnetotellurikus mérések az Ózdi-medencében. — A Magyar Állami Eötvös Loránd Geofizikai Intézet 1988-89. évi jelentése, 47-50.

Milota, K., KovÁcs, A. \& Galicz, Zs. 1995: Petroleum potential of the North Hungarian Oligocene sediments. — Petroleum Geoscience 1, 81-87. https://doi.org/10.1144/petgeo.1.1.81

Nagymarosi, A. 1990: Paleogeographical and paleotectonical outlines of some intracarpathian Paleogene basins. - Geologický Zbornik-Geologica Carpathica 41/3, 259-274.

Nagymarosi, A. 2012: Hungarian Palaeogene Basin. — In: HaAs, J. (ed.), HÁmor, G., Jámbor, Á., KovÁcs, S., Nagymarosy, A. \& SZEDERKÉNYI, T.: Geology of Hungary, Springer, 83-102. https://doi.org/10.1007/978-3-642-21910-8

PANTó G. 1956: A rudabányai vasércvonulat földtani felépítése. — A Magyar Állami Földtani Intézet Évkönyve 44/2, Budapest, 335-490.

Petrik, A., BeKE, B., FodOR, L. \& LuKÁCs, R. 2016: Cenozoic structural evolution of the southwestern Bükk Mts. and the southern part of the Darnó Deformation Belt (NE Hungary). — Geologica Carpatica 67/1, 83-104. https://doi.org/10.1515/geoca-2016-0005

Petrik, A., BeKe, B. \& Fodor, L. 2014: Combined analysis of faults and deformation bands reveals the Cenozoic structural evolution of the southern Bükk foreland (Hungary). — Tectonophysics 633, 43-62. http://dx.doi.org/10.1016/j.tecto.2014.06.029

Petrovics I. \& Szalay I. 1992: Reflexiós mérések az Ózd-Putnoki medencében. — A Magyar Állami Eötvös Loránd Geofizikai Intézet 1990. évi jelentése, Budapest, 20-27.

Posewitz T. 1906: Petroleum és aszfalt Magyarországon. — A Magyar Királyi Földtani Intézet Évkönyve 15/4 (záró) füzet, Budapest, Franklin Társulat könyvnyomdája, 236 p.

Püspöki, Z., Hámor-Vidó, M., Pummer, T., SÁri, K., Lendvay, P., Selmeczi, I., DetZky, G., Guthy, T., Kiss, J., Kovács, Zs., Prakfalvi, P., McIntosh, R.W., BudAY-Bódi, E. \& MARKos, G. 2017: A sequence stratigraphic investigation of a Miocene formation supported by coal seam quality parameters — Central Paratethys, N Hungary. — International Journal of Coal Geology 179, 196-210. https://doi.org/10.1016/j.coal.2017.05.016

RADócz Gy. 1966: A Bükk hegység környéki Helvéti képzódmények mélyföldtani térképe M=1:100 000. — A Magyar Állami Földtani Intézet kiadványa, Budapest.

RADócz Gy. 1987a: Földtani szelvények a Dél-Szlovákiai és Észak-Magyarországi medencékből. — Kézirat, Magyar Földtani, Geofizikai és Bányászati Adattár, Budapest.

RADócz Gy. 1987b: Újabb Rzehakiás (Oncophorás) rétegek a Ny-borsodi medence kőszénösszletéből. — Kézirat, Magyar Földtani, Geofizikai és Bányászati Adattár, Budapest.

RoYden, L. H. \& BÁLdI, T. 1988: Early Cenozoic tectonics of the Pannonian Basin system. — In: RoYden, L. H. \& HorvÁtH, F. (eds): The Pannonian Basin. AAPG Memoir 45, 27-48.

RozlozSNYIK P. 1939: Geológiai tanulmányok a Mátra É-i oldalán, Parád, Recsk és Mátraballa községek között. — Magyar Királyi Földtani Intézet Évi Jelentése 1933-35. II, Budapest, 545-620.

ROZLOZSNYIK P. 1941: Jelentés a recski kincstári bányában észlelt olajfelfakadásról. — A Magyar Királyi Földtani Intézet Évi Jelentése 1936-38. I, Budapest, 209-221.

SCHMOKER, J. W. 1994: Volumetric calculation of hydrocarbons generated. — In: MaGoon, L. B. \& Dow, W. G.: The petroleum system — from source to trap. AAPG Memoir 60, 323-326. https://doi.org/10.1306/0c9b0689-1710-11d7-8645000102c1865d

SCHRÉTER Z. 1936: Jelentés az 1936-ban végzett gyakorlati irányú földtani felvételekrôl (Bükkszék). — Kézirat, Budapest, MÁFGB Adattár T-65.

SCHRÉTER Z. 1942: Bükkszék környékének földtani és hegyszerkezeti viszonyai. — A Magyar Királyi Földtani Intézet Évi Jelentése 1936-38, Budapest, 831-886.

SCHRÉTER Z. 1951: Jelentés a további ásványolajfeltárások irányítása érdekében Bükkszék környékén végzett földtani vizsgálatokról. — A Magyar Állami Földtani Intézet Évi Jelentése 1945-47. II, Budapest,121-134.

SzALAY I. 1971: Összefoglaló jelentés Ózd és az Upponyi-hegység között végzett geofizikai kutatás eredményeiről. — Kézirat, MÁELGI, Magyar Földtani, Geofizikai és Bányászati Adattár, Budapest, SzÁF-55.

SzALAY I. 1976: Jelentés az 1975. évi Darnó-vonal környéki geofizikai mérésekról (Uppony-Rudabánya-Mátra-Szögliget-Abod). — Kézirat, MÁELGI, Magyar Földtani, Geofizikai és Bányászati Adattár, Budapest, Kx-36.

SZALAY I. 1998: Zárójelentés a Bükk hegység és előterei geofizikai kutatásáról 1986-1997. - Kézirat, ELGI. Magyar Földtani, Geofizikai és Bányászati Adattár, Budapest, AD. 1679, p. 27.

SZALAi I. \& ZELENKA T. 1979: A Darnó-vonal jelentősége Észak-Magyarország szerkezetfejlődésében. —Általános Földtani Szemle 13, 7-31. 
SzAlay I. \& Albu I. 1986: Az Aggteleki-karszt és Rudabányai hegység geofizikai előkutatása. — Kézirat, MÁELGI, Magyar Földtani, Geofizikai és Bányászati Adattár, Budapest, AD.642.

Szalay I., TABA S. \& SchőNvinszky L. 1987: Jelentés a Darnó-öv 1976. évi geofizikai kutatásáról. — Kézirat, MÁELGI, Magyar Földtani, Geofizikai és Bányászati Adattár, Budapest, T.10693, 33 p.

SZALAY I., SchŐNVISZKY L., KIRÁLY E. \& BRAUn L. 1988: Jelentés a Bükk hegység és környezete 1987. évi geofizikai előkutatásáról. — Kézirat, MÁELGI, Magyar Földtani, Geofizikai és Bányászati Adattár, Budapest, T.17950., 30 p.

SzENTES F. 1951a: A Bükkszéki kísérleti bánya földtani tanulságai. — A Magyar Állami Földtani Intézet Évkönyve 40/II, 23 -32.

SzENTES F. 1951b: Fedémes környékének hegyszerkezeti viszonyai. — A Magyar Állami Földtani Intézet Évi Jelentése 1945-47/II, 157161.

SZENTPÉTERY, I. 1997: Sinistrial lateral displacement in the Aggtelek-Rudabánya Mts. (North Hungary) based on the facies distribution of Oligocene and Lower Miocene formations. - Acta Geologica Hungarica 40, 265-272.

SzŐCs E., HIPS K., JózsA S. \& BENDő Zs. 2015: A kora-miocén Pétervásárai Homokkő diagenezis-története. — Földtani Közlöny 145/4, 351-366. https://ojs3.mtak.hu/index.php/foldtanikozlony/article/view/125

SzŐCs, E. \& HIPS, K. 2018: Multiphase carbonate cementation in the Miocene Pétervására Sandstone (North Hungary): implications for basinal fluid flow and burial history. — Geologica Carpathica 69/6, 515-527. https://doi.org/10.1515/geoca-2018-0030

SzTANó, O. 1994: The tide-influenced Pétervására Sandstone, Early Miocene, Northern Hungary: Sedimentology, palaeography and basin development. - Geologica Ultraiectina 120, 155 p.

SzTANó, O. \& TARI, G. 1993: Early Miocene basin evolution in Northern Hungary: Tectonics and Eustacy. — Tectonophysics 226, 485502. https://doi.org/10.1016/0040-1951(93)90134-6

TANÁCs J. \& RÁLISCH L.-NÉ 1990: Prekainozoos medencealjzat térkép. — Kézirat, Magyar Állami Földtani Intézet, Magyar Földtani, Geofizikai és Bányászati Adattár.

TARI, G., BÁLdI, T. \& BÁLDI-BEKE, M. 1993: Paleogene retroarc flexural basin beneath the Neogene Pannonian Basin: a geodynamic model. — Tectonophysics 226, 433-455. https://doi.org/10.1016/0040-1951(93)90131-3

Telegdi Roth, K. 1937: Die neuesten Resultate der Petroleum-schürfungen in Ungarn. — Festschr. Berg-Hüttenm. Jahrbuch Mot. Hochschule Leoben, Wien, 330-336.

TELEgDi Roth K. 1951: A Bükkszéki ásványkutatás és termelés földtani tanulságai. — Magyar Állami Földtani Intézet Évkönyve 40/2, Budapest, 3-22.

TóTH M. 1882: Magyarország ásványai. — Budapest, 565 p.

VARGA P. 1982: A tardi agyag alsó tengeri szintjének kora, allodapikus mészkőbetelepülések alapján. — Földtani Közlöny 112, 177-184.

VAss, D., ElečKo, M., Pristaš, J., LeXA, J., Hanzel, V., Modlitba, I., JÁnová, V., Bodnár, J., Husák, L., Filo, M. \& MáJovskÝ, J. 1989: Geologia Rimavskej Kotliny. Geology of Rimavská Kotlina depression. — Geologický Ústav Dionýza Štúra, Bratislava, 162 p.

VASS, D. 2002: Unique Cenozoic lithofacies in the northern part of the Darnó Fault Belt and its surroundings: an overview. - Acta Geologica Hungarica 45, 79-99.

VETő I. 1997: Szénhidrogén keletkezés és elsôdleges migráció. — In: JuHÁsz E., KuMMER I. (szerk.), Bucsi SZABÓ L., BuDAI T., DETZKY G., DetZKyné Lőrincz K., Dudkó A., FARKasné Bulla J., Fodor B., Hámorné Vidó M., Jámbor Á., Jocháné Edelényi E., Király E., Korpás L., Kovácsvölgyi S., Lendvay P., Madarasi A., Markos T., Müller T., Nádor A., Partényi Z., Polcz I., Rálisch L.NÉ, Redlerné TÁtrai M., Sebestyén I., SZeidovitz Gy.-NÉ, SZAlay I., Szőts A., Tóthné Makk Á., Treszné SZabó M., Varga S. \& VETô I. 1997: Magyarország szénhidrogén potenciálja az 1995. december 31-i állapotra. — Kézirat, Készült a Magyar Állami Földtani Intézet és az Eötvös Loránd Geofizikai Intézet „Szénhidrogén potenciál felmérés és medenceanalízis” c. közös projektje keretében, a Magyar Geológiai Szolgálat közremúködésével. Magyar Földtani, Geofizikai és Bányászati Adattár, Budapest,T. 19781

Völgyi L., Szerecz F., Hajdú D., Kurucz B., Mészáros L., Németh G., FöldeÁk P.-NÉ, Szentgyörgyi K.-NÉ, Horváth R., Kovács Zs., ToRMÁsSYNÉ VARGa É., DALlos E.-NÉ, NAGY M.-NÉ \& SzŰCS L. 1985: Magyarország kőolaj- és földgázelőfordulásai 1935-1985. — Kézirat, GEOS, Budapest, Magyar Földtani, Geofizikai és Bányászati Adattár, ELGI AD.553, 1038 p.

ZELENKA, T., BAKSA, Cs., BALlA, Z., FÖLDESSY, J. \& FÖldESSY-JÁRÁNYI, K. 1983: The role of the Darnó Line in the basement structure of Northeast Hungary. — Geologický Zbornik-Geologica Carpathica 34, 53-69.

Kézirat beérkezett: 2019. 09. 25. 
